\title{
Republic of Serbia: Financial Sector Assessment Program Update- Technical Note on Systemic Liquidity Management
}

This Technical Note on Systemic Liquidity Management on the Republic of Serbia was prepared by a staff team of the International Monetary Fund as background documentation for the periodic consultation with the member country. It is based on the information available at the time it was completed on March 2010. The views expressed in this document are those of the staff team and do not necessarily reflect the views of the government of the Republic of Serbia or the Executive Board of the IMF.

The policy of publication of staff reports and other documents by the IMF allows for the deletion of market-sensitive information.

Copies of this report are available to the public from

International Monetary Fund • Publication Services

700 19th Street, N.W. • Washington, D.C. 20431

Telephone: (202) 6237430 • Telefax: (202) 6237201

E-mail: publications@imf.org • Internet: http://www.imf.org

\section{International Monetary Fund Washington, D.C.}




\title{
FinANCIAL SECTOR ASSESSMENT PROGRAM UPDATE \\ REPUBLIC OF SERBIA
}

\author{
SYSTEMIC LIQUIDITY MANAGEMENT \\ TECHNICAL NOTE \\ MARCH 2010
}

INTERNATIONAL MONETARY FUND

MONETARY AND CAPITAL MARKETS DEPARTMENT
THE WORLD BANK

FinANCIAL AND PRIVATE SECTOR DEVELOPMENT

VICE PRESIDENCY

AfRICA REGION VICE PRESIDENCY 
Glossary .5

I. Monetary Management in Serbia: Systemic Aspects ................................................6

A. Monetary strategy and the caveats of Euroization ...........................................6

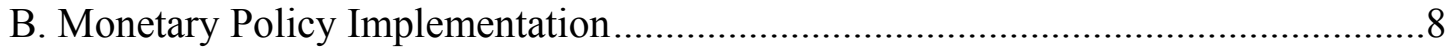

C. The Missing Link: Embryonic Money Markets and Commercial Banks’ Liquidity Management........................................................................................... 11

D. Detaching structural liquidity draining from signaling by using T-bills ...............14

II. Toward Deeper Money Markets and Greater Dinarization of Balance Sheets ..................17

A. A Strategic Roadmap Toward De-Euroization ..................................................18

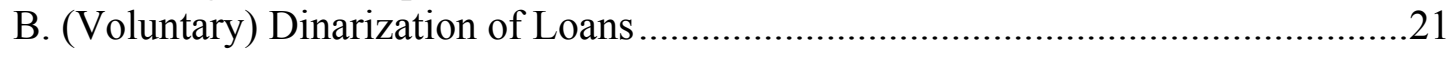

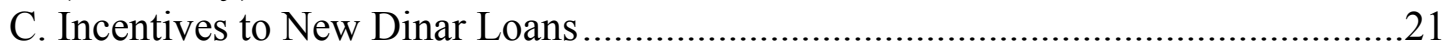

III. The Crisis Liquidity Management Framework ......................................................21

A. Collateral Policy Issues ......................................................................... 22

B. Public Sector Backing of Financial Stability-Related Operations ........................23

IV. Developing the Government Securities Market .....................................................23

Tables

1. Key Drivers of the Systemic Liquidity Situation............................................ 10

2. Asset and Liabilities of the Serbian Banking System ...........................................22

Figures

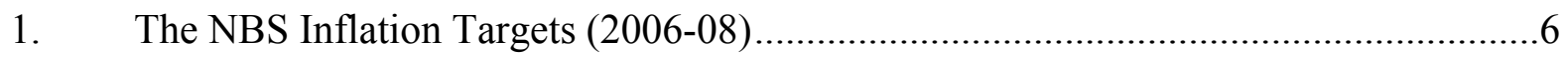

2. Currency and Deposit Substitution ................................................................... 7

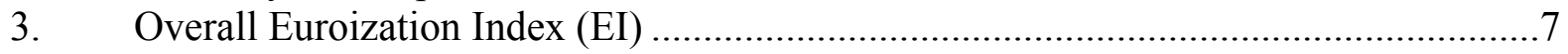

4. BEONIA in NBS Interest Rates Corridor and Standard Deviation .......................... 9

5. Cumulative Distribution of Average Distribution of Average Allocated RR.............10

6. Financial Assets Ownership Breakdown per Sector in Serbia.................................17

7. Stock of T-bills per Maturity and Auction Key Features .........................................24

8. Channeling of Flows between the NBS, the Treasury and Commercial Banks ..........35

9. Channeling Liquidity in System Where T-bills Would be Used ...............................36 
Boxes

1. Policy Options Available to Streamline the Reserve Requirement Framework..........13

2. Successful De-dollarization Experiences: Common Features ....................................19

3. T-bills for Monetary Management, Advantages and Key Challenges.........................38

Appendixes

I. A Strategy for the Dinarization of FX Loans.................................................. 31

II. Using T-bills Issuance as a Monetary Management Instrument................................35

Appendix Table

Selected Country Experiences with Specific De-dollarization Measures..............................26 


\section{GLOSSARY}

$\begin{array}{ll}\text { BEONIA } & \text { Belgrade Overnight Index Average } \\ \text { CB } & \text { Central bank } \\ \text { DMO } & \text { Debt Management Office } \\ \text { ECB } & \text { European Central Bank } \\ \text { EMU } & \text { European Monetary Union } \\ \text { EUR } & \text { European } \\ \text { EU } & \text { European Union } \\ \text { FCD } & \text { foreign currency deposits } \\ \text { FSAP } & \text { Financial Sector Assessment Program } \\ \text { FSSP } & \text { Financial Sector Support Program } \\ \text { FX } & \text { Foreign exchange } \\ \text { IMF } & \text { International Monetary Fund } \\ \text { ISIN } & \text { International securities identification number } \\ \text { IT } & \text { Inflation targeting } \\ \text { LCD } & \text { local currency deposits } \\ \text { LOLR } & \text { Lender of last resort } \\ \text { MOF } & \text { Minister of Finance } \\ \text { NBS } & \text { National Bank of Serbia } \\ \text { OENB } & \text { Central Bank of Austria } \\ \text { OMO } & \text { Open market operation } \\ \text { RTGS } & \text { Real-time gross settlement } \\ \text { RR } & \text { Reserve requirement } \\ \text { T-bills } & \text { Treasury bills } \\ \end{array}$




\section{Monetary Management in Serbia: Systemic ASPects ${ }^{1}$}

1. Serbia has made remarkable progress in monetary management since the 2005 Financial Sector Assessment Program (FSAP). The decision to move towards inflation targeting (IT), the related streamlining of its monetary policy framework, and reforms of the money and foreign exchange (FX) market have strengthened the National Bank of Serbia's (NBS) monetary policy formulation and implementation. However, the high level of Euroization represents a challenge to this framework, and the NBS has had nontraditional monetary policy instrument such as reserve requirement (RR) on Euro denominated liabilities.

\section{A. Monetary strategy and the caveats of Euroization}

Figure 1. The NBS Inflation Targets (2006-08)

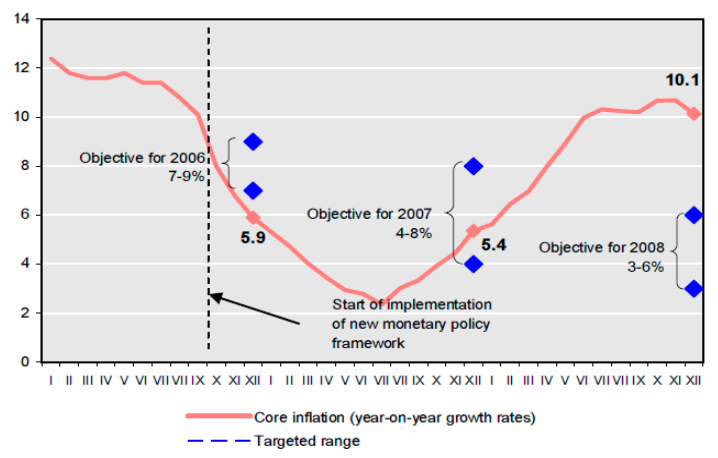

2. NBS's IT strategy allows more discretion and more impact on monetary policy stance in Serbia, but this impact is limited by structural features of the financial system. Still in its early phase of implementation, this policy leads to lower inflation (Figure 1). However, the structure of the financial system casts some doubt on the current scope for effective monetary policy. Active monetary policy via the use of an interest rate as operational target requires that effective channels of monetary policy transmission. The current degree of Euroization suggests that the interest rate channel is less effective. In addition, the credit channel has little scope for effectiveness, as most asset expansion so far has originated from external funding and/or euro deposit growth, which are not affected by the interest rate policy of the NBS, or only indirectly by the level of RR on euro liabilities.

3. Euroization levels are high, relative to peers in the region, and have not come down despite favorable conditions.

- $\quad$ Recent survey data, gathered by the Central Bank of Austria (OENB), show that Serbia's level of Euroization is the highest in Eastern Europe, but also the most pervasive in terms of share of deposits ( 88 percent) and cash holdings (75 percent) (Figure 2). Unlike regional peers, where Euroization is essentially financial, euro bank notes represent a proportion of currency in circulation that is commensurate with deposits.

\footnotetext{
${ }^{1}$ Technical note prepared by Alexandre Chailloux, MCMCM. David Vavra (MCMCM consultant) provided guidance and a technical addendum in appendix II.
} 
Figure 2. Currency and Deposit Substitution

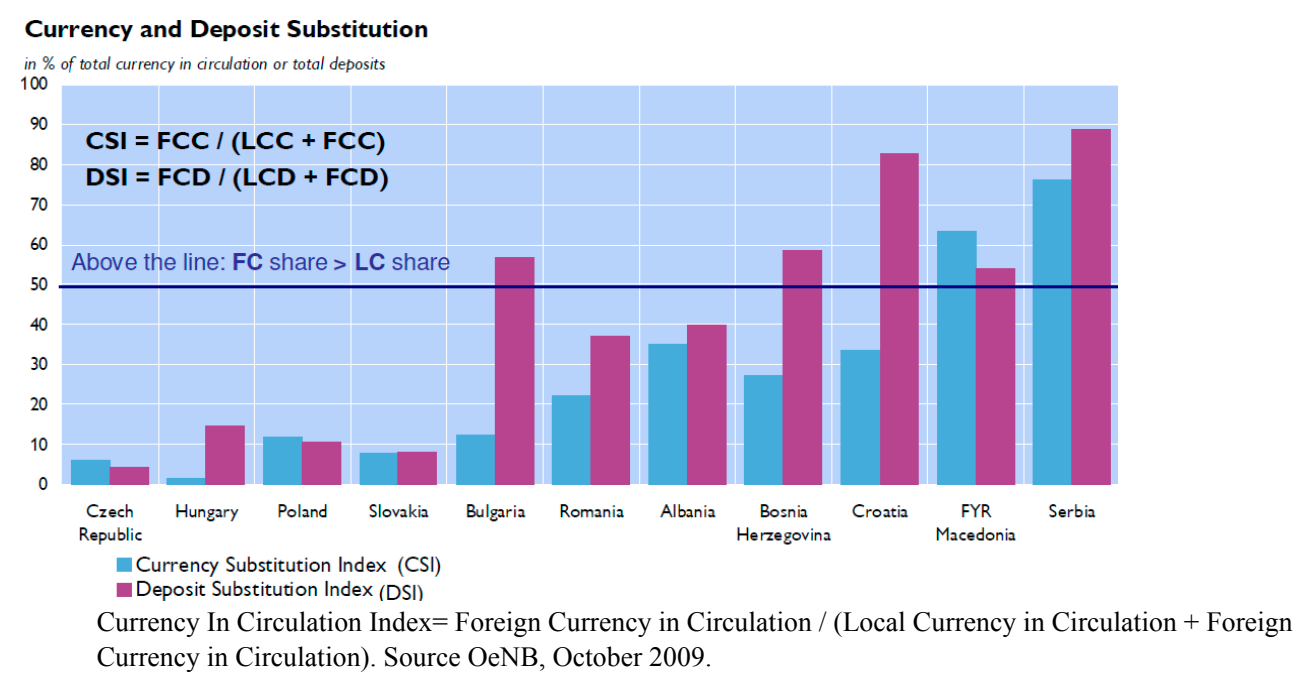

- Serbia has the highest Euroization Index in the region, calculated by the OENB (Figure 3). This index reflects the Euroization of balance sheets in Serbia. The portion of dinar lending to corporations is small: 77 percent of loans are either euro-indexed or extended directly in euro. ${ }^{2}$

- In the wake of the crisis, Euroization seems to have gained momentum rather than receded, in spite of favorable conditions for dinar loans in terms of lower inflation, declining interest rates, and a faster decline of RRs on dinar liabilities.

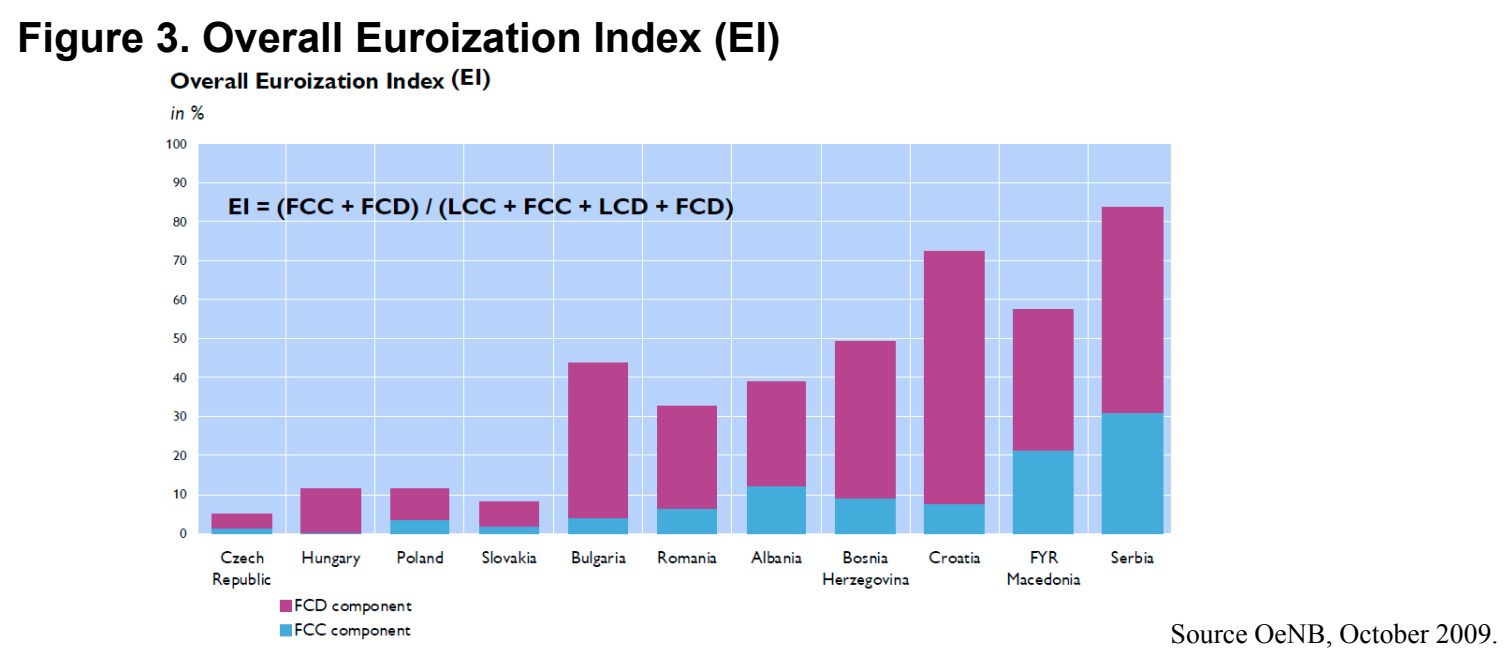

4. The current level of Euroization is posing a severe challenge to active monetary policy. As International Monetary Fund (IMF) research suggests, the existence of managed exchange rate regimes, a narrow base of domestic nominal financial assets, and the lack of

\footnotetext{
${ }^{2}$ The fulfillment of RRs on EUR liabilities in dinar mechanically increases the dinar share of banks' assets. Still, this higher share does not necessarily translate into higher dinar lending. The higher share of dinar assets of late reflects a change in the composition of assets towards the NBS repo and T-bills.
} 
market instruments to hedge exchange rate risks, with fear of floating and Euroization, are factors that weaken the efficacy of monetary policy. ${ }^{3}$ Still, these limitations, which impose differences in both the transmission capacity of monetary policy and its impact on real and financial sectors, do not preclude the use of IT as a policy regime.

5. The current environment implies that the only potential channel of monetary policy transmission likely to be effective is the exchange rate, but experiences from other countries are mixed. ${ }^{4}$ NBS interest rate decisions, by affecting the portfolio choices of economic agents between dinar and EUR denominated assets, would affect the exchange rate, whose movements would help to steer inflation towards its target. Although this link is supposed to be the main lever of interest rate policy, it is unclear how far the NBS repo rate has affected the exchange rate over the first two years, in the context of generally rising risk premia for emerging market currencies, and reversal of capital flows.

6. It is therefore desirable to increase the effectiveness of monetary policy through more traditional interest rate and credit channels by promoting Dinarization. Much of the discussion below relates to this objective, via improving the functioning of the dinar money markets and deepening them (including for government securities), and more direct measures and incentives.

\section{B. Monetary Policy Implementation}

\section{Monetary policy implementation has been successfully streamlined since the} introduction of IT. The creation of an interest rate corridor has helped strengthen the signaling role of the repo rate, and the dinar reserve management framework has been adjusted to smooth out further daily developments in the BEONIA rate. However, embryonic dinar money market features a very efficient overnight segment, and NBS' liquidity forecasting has been successful, in spite of the constraints posed by a very large outstanding amount of repo operations.

\section{Liquidity management by the NBS: Technical aspects}

8. The NBS liquidity management framework operates under the constraint of a fixed interest rate framework. The NBS repo, as the key instrument to signal monetary policy stance, was set up as a fixed rate instrument. The NBS repo operates as a de facto standing facility with all the bids presented by banks generally accepted. This implies that the NBS cannot materially target a given level of excess reserves at the end of the maintenance period.

\footnotetext{
${ }^{3}$ Inflation Targeting in Dollarized Economies; Leonardo Leiderman, Rodolfo Maino, and Eric Parrado, IMF Working Paper 06/157, June 1, 2006.

${ }^{4}$ This finding is validated by some research studies published by the NBS, inter alia, Aleksic, M., Lj. Djurdjevic, M. Palic, and N. Tasic, 2008, Interest Rate Transmission in a Dollarized Economy: the Case of Serbia, NBS Working Paper, Tasic, N., 2008, Pass-Through of Exchange Rates to Prices in Serbia: 2001-2007, NBS Working Paper, Palic, $\mathrm{M}$ and S. Vilaret, 2006, Exchange rate pass-through effect on prices in Serbia, NBS Working Paper.
} 
9. In spite of this constraint, the NBS has managed recently to smooth successfully the daily changes in the BEONIA index, and has prepared accurate forecasts of repo use (Figure 4). The autonomous factors of liquidity are forecasted using various econometric tools that have shown a high degree of accuracy. For example, an ARIMA model is used for currency in circulation forecast, based on different moving averages and lagged values to forecast the short-term demand for bank notes.

10. Balances on the treasury account are difficult to forecast due to limited provision of forward-looking information by the treasury. The lack of discipline in the use of the Ministry of Finance (MOF) information system for budget execution generates significant uncertainty on the near-term cash flow pattern for the treasury and thus prevents the production of reliable forecasts (Table 1). Liquidity managers resort to average value for previous years and seasonal patterns to infer the likely levels of the treasury balances within the current maintenance period.

Figure 4. BEONIA in NBS Interest Rates Corridor and Standard Deviation
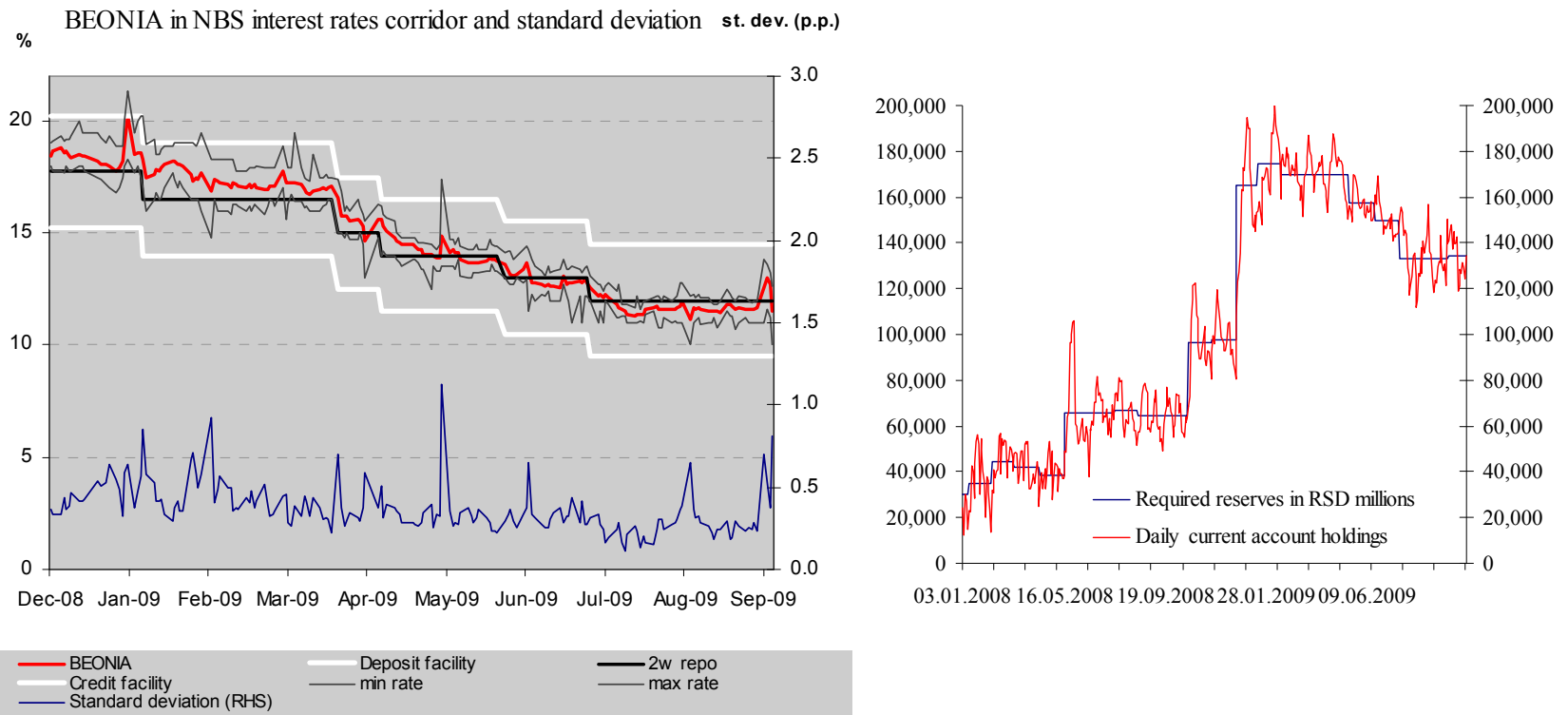


\section{Table 1. Key Drivers of the Systemic Liquidity Situation During the Course of the Maintenance Period}

(Treasury Account with the NBS)

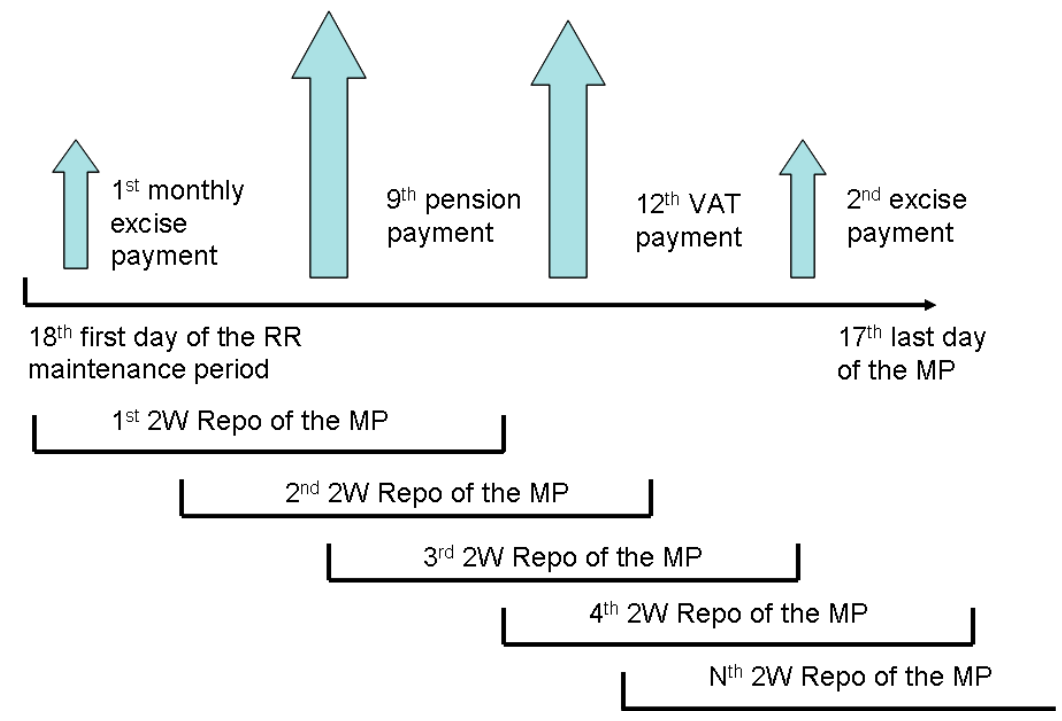

Figure 5. Cumulative Distribution of Average Allocated RR

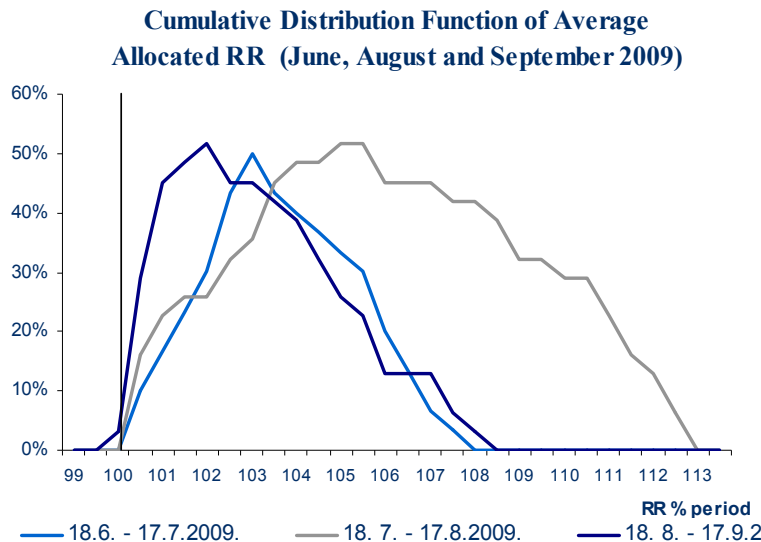

11. The liquidity management framework, while generally efficient, is constrained by instability in the demand for excess reserves. The demand for excess reserves is generally a function of the quality of the systemic liquidity management by the central bank, the technical capability of commercial banks' treasurers to manage their balances adequately, and the overall efficiency of payment systems facilities for money market participants. The relatively high and unstable demand for excess reserves is therefore somewhat puzzling in Serbia (Figure 5). The NBS' liquidity management capacity is high; commercial bankers, especially the large foreign-owned banks, have efficient cash management standards. The real-time gross settlement (RTGS) system enables market participants to gain a clear picture of their prospective cash balances, owing to the real time irrevocable nature of cash transfers in the system.

12. This relatively high level and instability of excess reserves may be due to a number of factors. For example, the high spread between the NBS repo rate and the marginal lending facility (currently 250 basis points) may induce treasurers to keep further liquidity cushions 
(beyond RRs, in spite of the averaging provision) to avoid costly overdrafts. Another likely source of cash management uncertainty for bankers is the flexible timeline afforded to customers for their wholesale cash transfers. Because of the very high competition between banks to maintain their large corporations' customer base, banks have granted corporate treasurers the right to issue wholesale cash transfers until 5HPM. Consequently, the RTGS chronology leaves very little time for treasurers to adjust their cash balances via the interbank market.

\section{A more constraining RTGS chronology could help reduce the demand for excess} reserves. Standard rules in RTGS generally impose a mid-day cut-off time to customers operations, so that the afternoon session is dedicated to wholesale adjustments on the interbank market, and to the handling of the other residual exogenous system settlement flows (e.g., the Central Securities Depository). This flexibility left to corporate customers results in a large residual uncertainty for banks' treasurers, whose cash balance can be drawn very late in the day without notice. A more constraining chronology (i.e., earlier cut-off times for customer wholesale payments) would go a long way towards reducing treasurers' end-of-the day uncertainty, and likely reduce the demand for excess reserves.

\section{The Missing Link: Embryonic Money Markets and Commercial Banks' Liquidity Management}

14. The dinar money market, however efficient on its overnight segment, is embryonic on the term segment due to euroization of balance sheets. Ninety-eight percent of the turnover is in overnight operations, the residual being Tom-Next and Spot-Next operations. The market does not feature traditional segments of modern money markets, like CPs, CDs, and interbank repo operations. High euroization allows Treasurers to manage their liquidity on the euro part of their balance sheet more actively by accessing channels offered by their head offices, or by using euro-denominated liquid assets on the euro money and repo market. They can also handle liquidity gaps arising on their dinar portfolio by using euro liabilities and FX spot operations, or FX swaps, provided that their net open FX position gives them the sufficient leeway to carry out these operations.

15. Because of the flexibility afforded by the euro share of their assets and liabilities, treasurers have little incentive to manage their dinar liquidity more actively. Therefore, the market activity focuses essentially on NBS operations, and treasurers use the 2-week repo to "park" their dinar liquidity. Recently, the increasing issuance of T-bills has provided them with an investment alternative. Still, the banking industry's reliance on NBS operations has increased substantially. From an outstanding of 70 billion dinar, the repo has recently gone up to 185 billion dinar (in November 2009).

\section{The large outstanding amount of NBS repo operations: Issues}

16. The NBS repo operations are convenient for banks, but pose two inconveniences. First, the reserves deposited with the NBS are an alternative to bank lending in dinar, which 
contribute to lower dinar share of total assets (no "multiplier effect"). Second, it limits NBS' room for maneuver. The 2-week NBS bill repo is used both to signal the monetary policy stance, and operates de facto as a standing facility. This duality poses a potential challenge, as the rapidly increasing cost of sterilization may over time come into conflict with the monetary policy signaling role. In addition, this facility invites carry-trade and short-term capital inflows, while having arguably little impact on domestic credit conditions, because of the current magnitude of Euroization. For this reason, the NBS should envisage additional instruments to deal with the structural liquidity surplus in a more active way (i.e., by using other more cost-effective channels than the repo for liquidity draining). A more appropriate set-up would allow for separating the monetary stance of the central bank, as expressed by the repo rate, from the cost of structural sterilization operations. This could be achieved by other potentially less costly means and would also help in discouraging destabilizing capital flows.

\section{A complex reserve requirement framework}

\section{The high level of RRs on EUR liabilities should be reassessed in the current context} of weak asset growth (Box 1). The 40 percent-unremunerated RR rate is, by regional standards, extremely tight. The RR has served the NBS well, by increasing the funding cost of eurodenominated banking operations and limiting credit expansion, and also creating a liquidity buffer that would help banks to withstand liquidity pressures (in case additional funding from the parent would not be available). However, it has also brought adverse impact such as the surge in offshore banking towards corporations, which contributed to lower bank profitability in Serbia.

\section{Banks' funding costs could be eased by reducing RRs or by remunerating RRs.} Although there is little certainty about the final use of the liquidity that would be thus released, a reduction in RR would help decrease banks' euro-funding costs, and give them some breathing space to expand their assets in either euro or dinar. Alternatively, the NBS could maintain its control on euro credit while reducing banks funding cost by remunerating, even partly, RRs in dinar. This could contribute to increasing banks' appetite for dinar assets.

\section{The potential negative impact of remunerating RRs on NBS revenues should not be} regarded as an impediment. The NBS has been making profits throughout the crisis and RRs is only one element in the determination of the NBS revenues. For instance, lower outstanding repo operations could offset the revenue impact of lower unremunerated RRs. A potential side effect of lower RRs on euro liabilities is the risk of perpetuating the interest rate wedge in favor of euro loans. The decrease in the euro funding costs that would follow a cut in RRs could impede the NBS' dinarization agenda. For this reason, any reduction in euro RRs should be offset by a decision that would at least yield a similarly beneficial impact on dinar assets and liabilities. 


\section{Box 1. Policy Options Available to Streamline the RR Framework}

The reform of the RR framework should aim at the three following goals:

1. Allow RR to play a less pro-cyclical role (allow asset expansion, reduce banks' funding costs).

2. Simplify the complex net of regulations and exemptions to facilitate banking operations and reduce ancillary costs.

3. Facilitate, when feasible and based on positive incentives, a re-channeling of bank assets towards dinar-denominated assets and loans, for a more effective interest rate channel of monetary policy.

The current environment provides a clear window of opportunity to meet these three objectives. Bank profitability is under pressure because of worsening asset quality, in a context where asset growth will remain, in most optimistic scenario, in the single digit range. The overall streamlining of the RR framework could comprise the following measures:

4. RRs on FX liabilities should be reduced gradually to 30 percent and later to 20 percent if it turns out that asset growth remains subdued. In the context of the Vienna agreement, banks will not have the option to send back the EUR so released to the parent bank. They will have the following alternatives: expand their EUR portfolio, buy dinars to invest in the NBS repo, and/or expand their loan portfolio. Alternatively, a re-negotiation of the Vienna agreement commitment would give them the additional option of returning these euros to the mother bank. A 10 percent cut in RR would release around 500 million euros.

5. The mismatched currency fulfillment of RRs should be gradually phased-out. Initially introduced to relieve banks' EUR funding stress, this measure is no longer warranted. The EUR drain generated by this measure could be partially offset by the blanket cut in RRs discussed above. Some of the EUR released above could meet the higher needs coming from the currency-matched fulfillment. The dinar released by this measure could be used by banks to purchase EUR or to invest in dinar securities

6. Post-September 2008 EUR RR exemptions should be discontinued. The costs savings achieved by banks through this measure would be offset by the blanket cut on EUR RRs.

7. EUR RR exemptions related to the distribution of subsidized loans should be discontinued.

8. RRs on dinar liabilities should be remunerated. This remuneration would go a long way towards reducing the interest rate differential in favor of EUR loans and would support balance sheet expansion in dinar-denominated assets. Costs for the NBS would be limited in a first stage (because of the low outstanding of dinar loans). The NBS could present this measure as experimental, and announce that it would be maintained only based on evidence of commercial banks actually reflecting the related decrease of their funding costs on their lending conditions.

20. Alongside, the NBS should streamline the overall RR framework. The various exemptions (e.g., the zero RRs on overseas funding coming from mother banks above the September 2008 level), the mismatched fulfillment of euro RR in dinar and frequent amendments, and the exemption related to the distribution of subsidized loans, make enforcement by banks complicated and administratively burdensome. Most of the objectives of the reserve management framework could be achieved via a simpler framework (Box 1). For 
instance, the fulfillment of RR on euro liabilities in dinar was adopted to ease a liquidity squeeze in euro. Thanks to the Vienna agreement, the likelihood of a future bout of euro liquidity stress is low (barring a strong balance sheet expansion beyond the commitment levels), and the NBS' FX swap facility would meet banks' need to raise euro using dinar holdings, should this become necessary. The funding cost impact of a blanket reduction in the rate of RR on euro liabilities could more than offset the exemption granted to additional overseas funding received post September 2008. The NBS should also use this opportunity to tilt incentives towards a deEuroization of balance sheets.

\section{Detaching structural liquidity draining from signaling by using T-bills}

\section{New structural liquidity draining instruments based on treasury securities could} usefully leverage the ongoing development of the T-bills market. A partnership between the NBS and the treasury, whereby the debt management office (DMO) would gradually increase Tbills issuance, would serve the structural liquidity needs of the NBS. T-bills could be used by the NBS for liquidity management purposes in three different ways: (a) T-bills-based repo; (b) Tbills outright sales to market participants; and (c) the use of T-bills auction as liquidity draining instruments. The first two approaches are relatively similar in nature, while the third would rely on a different mechanism that would assume further treasury/NBS coordination for monetary management.

\section{The first and second approaches would require setting-up an outright portfolio of}

T-bills by the NBS. Instead of using, like central banks (CBs) operating in a liquidity shortage environment, outright purchases in the market to build up this portfolio (not consistent with Serbia's liquidity surplus environment), the NBS would need these securities to be transferred by the treasury as equity (as an endowment). This would strengthen the balance sheet of the NBS while giving it more operational flexibility. This transfer could be achieved through the regular auction schedule of the treasury, by allocating medium-term and long-term securities at the auction "cut-off price" to the NBS. The NBS would use this portfolio for liquidity draining operations.

23. The T-bills based repo approach would have several merits relative to an NBS based repo approach. First, the revenues accruing on the portfolio of T-bills would offset the cost of liquidity draining operations. ${ }^{5}$ Second, the T-bills-based repo could be designed such that their interest rates would not interfere with the monetary stance as expressed by the NBS repo. This could be achieved by using NBS repo only for short-term operations, and using T-Bills based repo for more structural liquidity draining operations, such as 3-months repo, with the NBS

\footnotetext{
${ }^{5}$ Whereas in the current case NBS repo are matched on the asset-side by FX currency holdings, materializing a "carrying cost" of FX reserves equal to the yield differential between the NBS repo rate and euro rates (around 8 percent).
} 
acting as a price-taker (by setting no rate limit to the auction). ${ }^{6}$ In principle, the rate on these operations should faithfully track the T-bills rate (and not necessarily the NBS repo rate).

24. This outright T-bills portfolio could be used, as suggested above, for reverse operations, but also for outright operations (option b). The NBS, in case of unforeseen change to structural liquidity conditions that would increase the overall liquidity surplus, could decide to sell a large part of its holdings to reduce this structural liquidity overhang. The caveat of a repeated use of outright sale would be the depletion of the portfolio.

\section{The third approach would be different in nature, and use the primary auction} process to drain surplus liquidity. The treasury would earmark a certain portion of its regular T-bills auctions (pursuant to the NBS guidance) as "issued for monetary management purpose." The proceeds of the "monetary management portion" of T-bills auctions would be placed in a special escrow account on the liability side of the NBS balance sheet and thus usefully replace the NBS repo operations (see Appendix II for more details). This approach would help scale down the outstanding amount of NBS repo, and implicitly transfer a portion of the NBS repo portfolio to the market outstanding of T-bills. This approach requires very effective technical coordination between the $\mathrm{CB}$ and the treasury and has been successfully implemented in a number of countries. It requires perfect coordination and a solid consensus on the CB's ways and means of implementing monetary policy. Its limitation is that it makes the $\mathrm{CB}$ reliant on the treasury and DMO for the conduct of liquidity management operations. In addition, the impact of this option on the cost of running liquidity draining operations may be limited if the treasury demands remuneration for the share of its positive balance that would come from this "issuance for monetary purpose." For this reason, such an approach is unlikely to be workable in Serbia.

\section{The Cost of Draining Liquidity: Burden-Sharing Considerations}

\section{These three partial alternatives to the NBS repo would have different consequences}

in terms of monetary policy cost burden-sharing. The transfer of treasury security to the CB to set up an outright portfolio can be seen as an investment for the treasury, whose claim would be remunerated by the NBS' increasing ability to generate seigniorage. ${ }^{8}$ Alternatively, letting the $\mathrm{CB}$ run monetary policy at a cost that would exceed its revenues and letting negative equity accumulate could have a negative signaling effect that may undermine NBS credibility going forward, and hence the value of the treasury worth (as shareholder). In addition, only interest costs would have to be considered in the short-run, as the treasury would roll over the securities

\footnotetext{
${ }^{6}$ That would be most similar to the way the ECB carried out its longer-term operations (LTROs, for which no minimum bidding rate was set) before the turmoil.

${ }^{7}$ The cost of draining liquidity using this approach would be the T-Bill rate and not the NBS repo rate. However, the Treasury, by imposing a market rate remuneration on the corresponding balances on its account, would ask the NBS to pay the interest on these bills (otherwise the DMO would borrow at 10 percent and place at 2.5 percent with the NBS).

${ }^{8}$ By contrast with the current situation in which the cost-of carrying FX reserves lowers on the NBS's revenue, and has to be offset by large and unremunerated reserve requirements.
} 
transferred upon maturity (the treasury would not redeem T-bills to the CB but re-issue to keep its equity claim on the NBS constant). Outright sales would create a different situation, as securities that would end-up in private hands would indeed have to be redeemed by the Treasury. The third approach would have a more ambiguous cost-impact, as only the remuneration of the "idle treasury balances" would determine the eventual cost to the NBS. More generally the idea of a trade-off between sharing the cost-burden of monetary policy upfront and letting the central bank support alone the cost of liquidity draining operations, and when the cost gets too high, accumulate losses (before subsequent recapitalization)is only apparent. From a consolidated fiscal standpoint, the fiscal authority should have no preference between contributing to the cost of monetary policy upfront and receiving a higher dividend (or seeing the CB building up a capital buffer), and letting the $\mathrm{CB}$ bear all the costs and receiving no dividends in the end.

27. Still, some institutional rigidities may bias the above trade-off towards an upstream support, such as the risks of political interferences when recapitalization measures have to go through a parliamentary process. The difficult fiscal situation of Serbia may undermine anyhow the idea of the treasury supporting upstream the cost of monetary policy, in exchange for a hypothetical dividend payment.

28. The three alternatives mentioned above could overall decrease the bill of structural liquidity draining operations. In the current context, the NBS repo rate acts as a de facto floor to T-bills issuance. A rationing of NBS repo volumes (that would be necessary to release some liquidity for other liquidity draining channels) would increase bankers' incentives to bid below the repo rate, and thus probably generate interest expense savings to the treasury and the NBS, ${ }^{9}$ thanks to the competitive bidding approach that would be used. The competitive pricing used for T-bills, in case of a larger demand for T-bills, could bring about lower rates that would represent cheaper sterilization for the NBS. An increase in the need for sterilization stemming from large portfolio flows would, in this framework, be self-defeating, as the larger amount available for Tbills investment would push their rates lower, and diminish incentives all along, thus preventing bouts of "carry strategies" to take hold in Serbia.

\section{As to whether a larger of supply of T-bills could be "digested" by the market, the} answer is twofold. First, the ex-ante decline in the stock of NBS repo implies that no "additional demand" will technically be needed. In addition, anecdotal reports suggest that banks would be keen on absorbing larger T-bills issues, notably on the longer-end of the T-bills curve (one year). Second, insurance companies, although representing a small share of Serbia's financial assets (around 4.25 percent) should represent an obvious investor base, notably in a context where life insurance is still underdeveloped and where insurance companies essentially have to hedge short-

\footnotetext{
${ }^{9}$ In this respect, the best way to help banks accommodate the "rationing" of the NBS repo would be to pair this decision with the announcement of the remuneration of dinar reserve requirements. The related drop in the dinar funding cost would create a new break-even rate for T-bills holdings, and push them to bid markedly below the repo rate at no cost. Although, technically, these two measures combined would not decrease balance sheets de-Euroization (because it would generate a mere repo/T-bills substitution), it would have an impact on the T-bills' rate, and hence likely drag all dinar rates lower by virtue of the anchoring on the T-bill curve.
} 
term liabilities (such as car insurance). An expansion of insurance companies' assets should certainly generate further bidding interests on the T-bills market. Developments towards life insurance would also support the supply of longer-term papers by the treasury (Figure 8).

Figure 6. Financial Assets Ownership Breakdown per Sector in Serbia

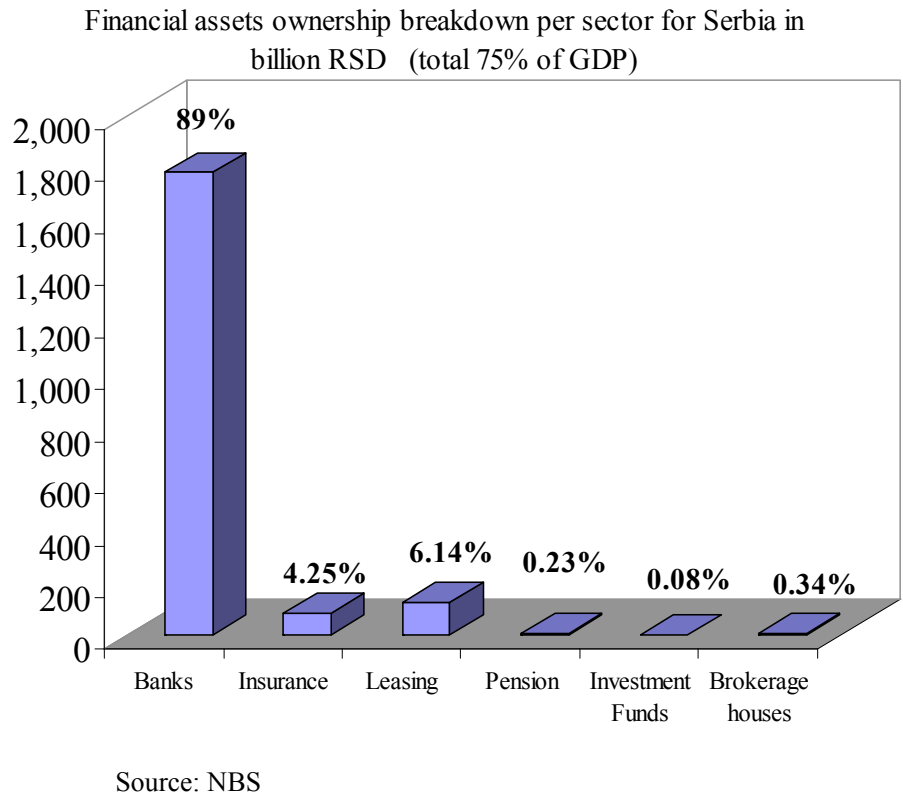

Long-term prospects for structural liquidity draining in Serbia

30. The three options presented above would have the merit of increasing the overall amount of dinar-denominated tradable public debt, which would present long-run benefits. This could help in de-connecting the issuance of debt from short-term treasury funding needs, and avoiding stop-and-go issuance patterns generated sometimes by short-term fiscal windfalls. It would also promote the de-Euroization of balance sheets and create positive externalities to the Serbian capital market (such as pricing references). In the longer run, a gradual re-balancing of the balance of payments and decreasing the reliance on foreign funding should allow a decline in the structural liquidity draining needs, a shrinking of the NBS balance sheet, and a declining need for sterilization (reduced frequency of FX interventions, move towards a purely floating exchange rate). The secular increase in the multiplier stemming from a larger recourse to the dinar (thanks to lower RRs), should drive the system towards a structural liquidity shortage, or, at least, a more balanced liquidity situation in which interest rates could be steered via at-themargin repo operations (i.e., a small outstanding).

\section{Toward DeEper Money Markets AND Greater Dinarization OF Balance SHeEtS}

31. The NBS should also gear its operational framework towards the objective of deepening the money market beyond the overnight market. A lower frequency NBS repo auction (once a week instead of twice), coupled with one single weekly auction session of T- 
bills, would create more scope for interbank operations on the term. Treasurers would have to manage some short-term liquidity gaps between auctions, instead of benefiting from the current frequency auction schedule as today. A tighter daily schedule for customers' large value payments in the RTGS (with a cut-off time around noon rather than 5:00 p.m.) would help treasurers gain visibility clearer picture on their prospective cash balance at the end of the day, thus diminishing the residual demand for excess reserves. This could contribute to a more balanced liquidity situation. Deepening the dinar market, beyond the mere point of the technical features of the NBS operations, will require concerted efforts on the part of monetary and fiscal authorities to tilt incentives towards a greater use of the dinar. We will try to outline the options that should be considered to this end.

\section{A. A Strategic Roadmap Toward De-Euroization}

32. Serbia's relatively recent background of hyper-inflation, of repudiation of domestic currency-denominated debt (dinar frozen deposit), and of a deeply-rooted habit of using the Deutschmark and later the euro as store of value, represent clear obstacles to a greater use of the dinar by banks, individuals, and corporations. The prominent role of foreign banks, for which the access to foreign currency funding represents a key competitive asset, also stands in the way of a greater use of the dinar. Finally, the constant stream of euro-denominated remittances is also an obstacle to the dinarization of commercial banks' liability sources.

33. De-dollarization generally comes on the heels of three types of policy actions that can be combined or used separately (and often sequentially):

- $\quad$ First, macro-economic stabilization policies generally bring about, thanks to lower inflation and two-way exchange rate risks, an environment conducive to the expansion of local-currency denominated banking assets.

- $\quad$ Second, more forceful measures, like forced conversion of loans, or the closing of capital and current account (inward restriction to financial flows and FDIs, surrender requirements) can in some circumstances be successful. In a number of cases though, a low level of enforcement, or the existence of regulatory loopholes, have undermined the impact of such measures and have aggravated the demise of local currencies.

- The third types of measures are the positive and negative incentives that can be used to tilt the overall balance of incentives towards a greater use of the domestic currency. These incentives can be budgetary (subsidies), supervisory (higher risk weights and/or capital charges on currency-denominated loans) and monetary (RRs). They all contribute marginally to the funding costs in domestic currency and foreign currency, so that a tipping point at which the interest rate wedge is no longer an obstacle to the local currency. 


\section{Box 2. Successful De-dollarization Experiences: Common Features}

De-Euroization is an essential prerequisite to improving the efficacy of monetary policy in Serbia. In most emerging market economies, de-dollarization typically occurs as an endogenous phenomenon, along with a marked reduction in the rate of inflation and not as a result of active and direct policies with that objective. Yet, the experience of countries such as Chile and Israel suggests that policymakers can also have a direct role in this process by contributing to the development and deepening of domestic financial markets. A working paper being prepared in $\mathrm{MCM}^{1}$ outlines the key components of the most successful experiences of dedollarization. Beyond the key macro-building block of a two-sided exchange rate risk and lower inflation, most countries, having restored a greater scope for the use of their currencies, have implemented specific measures that have furthered the impact of the aforementioned macro factors.

International examples of measures that have achieved noticeable de-dollarization outcomes (together with macro-economic stabilization):

- Mandatory holding period for deposits in foreign currency. (Israel).

- Withdrawal of the legal tender status from foreign currency. (Angola, Israel, Lao P.D.R., Peru, and many others).

- Requirement to list prices of goods and services in domestic transactions in local currency (sometimes coupled with the obligation to make payments in domestic currency).

- Regulations that discriminate against the use of foreign currency. Measures may include (a) imposing limits on foreign currency borrowing or lending (Angola, Argentina, Israel, Lebanon, and Vietnam); (b) excluding dollar deposits from the deposit insurance scheme (Uruguay); and (c) requiring additional provisions or capital for dollar loans to the nontradable sector (Honduras and Vietnam).

- Capital controls. The temporary imposition of surrender requirements on FX proceeds of residents in the context of a high level of convertibility may lead to a rapid decline in FX deposits. ${ }^{2} /$ In other cases (Mexico), the access to FCD was limited to some economic agents, such as firms.

Two recent de-dollarizations have been carried out in the context of a currency and banking crisis (Argentina and Pakistan). Although the measures forced de-dollarization, they were necessary to mitigate a banking crisis. In 1998, a political shock and the ensuing capital flight, declining reserves, and drying up of foreign liquidity forced the Pakistani authorities to withdraw the preferential treatment previously provided to foreign currency deposits (FCDs). In parallel with macroeconomic stabilization, the authorities introduced a temporary freeze on FCDs and a number of exchange controls. Later, frozen deposits could be withdrawn in domestic currency or converted into medium-term dollar-denominated bonds. Although the opening of new FCDs was allowed, the preferential tax treatment of FCDs and the convenient forward cover scheme for banks that had encouraged dollarization was discontinued. Following macroeconomic stabilization, conditions normalized and the stock of FCDs represented only a relatively small part of deposits. Similar measures were introduced in Argentina with a limited access to deposits by investors. In addition to limiting access to LCDs (corralito), the authorities introduced a freeze on FCDs to limit capital flight and prevent bank runs in 2001. Building on the results of macroeconomic stabilization, the freeze was abandoned in 2002, but the share of FCDs in private deposits remained significantly below the pre-crisis level, reaching only 8 percent by 2005 . The temporary freeze on deposits eroded the credibility of the banking system, as reflected in the slow pace of private deposit growth in the aftermath of the crises.

The success of de-dollarizations in noncrisis contexts typically cannot be attributed to microeconomic measures. ${ }^{3}$ In Chile, Israel, and Poland, the process began with a successful disinflation program leading to a more flexible exchange rate and a monetary policy aimed at lower inflation. De-dollarization was a by-product of macroeconomic stabilization. However, steps were taken in some or all of these cases to ensure that the 
prudential framework did not disadvantage the local currency, to create an interest rate wedge in favor of the local currency, and to shift debt issuance away from foreign-currency-denominated bonds.

The gradual stabilization program in Israel brought down inflation from about 400 percent in 1984 to single digits in the late 1990s. In addition to macroeconomic stabilization, policy aimed at decreasing the foreign-currency-denominated part of the public debt and supported the introduction of hedging instruments to manage foreign exchange risks. Israel implemented higher reserve rates on FCD, and offered alternative investment possibilities by introducing dollar-indexed deposits and inflation-indexed bonds. In addition, prudential rules were introduced on foreign currency-denominated loans to ensure adequate hedging of risks. These policies were reflected in the lengthening of the maturity of the public debt and a larger share denominated in domestic currency. Dollar-denominated deposits declined from 39 percent of total deposits in 1984 to 17 percent in 2002. The decrease in deposits indexed to consumer prices was less pronounced (Galindo and Leiderman, 2005). Dollarization thus exhibited considerable inertia even after a decade of low inflation, possibly reflecting lingering doubts about the credibility of monetary policy. Banking supervision played a key role in ensuring that banks meet the prudential requirements such as open position limits.

Chile's experience shows that indexation introduced to avoid dollarization may persist even after macroeconomic stabilization has been achieved. Despite the presence of indexation since the 1960s, Chile successfully stabilized the economy, liberalized the financial sector, and gradually dismantled controls on international capital movements (by the 1990s). ${ }^{4}$ The government also undertook a debt conversion scheme to change foreign-currency-denominated debt into indexed debt. Although Chile adopted inflation targeting and allowed the peso to float freely in 1999, indexation continued to be prevalent. It was ultimately reduced by targeting a fixed nominal interest rate instead of the inflation indexed "real" interest rate. Subsequently, peso deposits increased and reached 50 percent of total deposits in 2004.

In Poland, de-dollarization was encouraged by a successful reform program and tight monetary policy. In the early 1990s, following episodes of high inflation and frequent step devaluations, Poland embarked on a macroeconomic stabilization program, coupled with financial sector liberalization and the gradual opening of the capital account. In addition, domestic interest rates were raised well above foreign currency interest rates. The sharp reduction in inflation and interest rate deregulation establishing positive real interest rates resulted in an increase of zloty deposits to 50 percent of total deposits, while FCDs declined to 30 percent of broad money by end-1993 from 72 percent in 1989.

Egypt successfully de-dollarized in the context of macroeconomic stabilization and bank reform. The share of FX deposits to total deposits declined from 56 percent in 1991 to 22 percent in 1999 and further decreased to 18 percent by 2004. In 1991, the authorities launched a set of fiscal and monetary reforms to reduce inflation and liberalize the financial system, which was heavily controlled (credit ceilings, interest rate controls, and differential RRs). The liberalization of the banking system led to a significant decline in inflation, positive real interest rates, and ultimately to the decline in FCDs.

1/ "Dedollarization" IMF Working Paper (Forthcoming) by Kokeyne, Ley, and Veyrune.

2/ Under a general surrender requirement residents are obliged to sell their foreign currency receipts to local banks or the central bank. Hence, residents may not retain such receipts in foreign currency deposits.

3/ Reinhart, Rogoff, and Savastano (2003) identify four cases of successful dedollarization: Chile, Israel, Mexico, and Poland, based on the following criteria: deposit dollarization falls by 20 percentage points and remains below 20 percent.

4/ According to Herrera and Valdes (2004), capital controls on inflows helped to contain the accumulation of foreign exchange risk through excessive borrowing abroad. 
34. Greater use of the incentive-based approach is called for in Serbia (see Box 3 for a discussion of de-dollarization cases). Forceful measures are not a realistic option, not least because Serbia has not experienced a crisis so severe to vindicate such aggressive measures, but also because forced loans conversion, or capital account restrictions, would run counter to Serbia's pro-euro agenda, and prospects of European Monetary Union (EMU) membership.

35. We will focus here on two sets of measures that may help encourage the dinarization of banks' assets in Serbia's context, informed by other countries' experiences (Appendix Table 1).

\section{B. (Voluntary) Dinarization of Loans}

36. In the spirit of the FSSP, the NBS and the government should allow banks to alter the terms of existing euro and FX loans. Loan conversion standard procedures should include grace periods, lengthening of the terms, and re-scheduling options that will allow reducing the dinar installment to levels at least equal to the former euro cash-flows (i.e., to offset the interest rate differential in favor of euro debt). These loan restructuring measures should be offered not only to delinquent borrowers but also to all clients possibly exposed to FX risk (non-FX earners) who are servicing their debt on time. For these borrowers the idea of a subsidized reduction in the net present value of the loan should be envisaged.

37. The impact of these incentives would be magnified by a decrease in dinar funding costs of banks. This decrease could be achieved by a remuneration of dinar RRs at the NBS repo rate, or even at a higher rate, at least in the first stage (this measure would not be very costly in the beginning, considering the small outstanding of banks' dinar liabilities). This overremuneration could be gradually phased out once the dinarization process takes hold.

\section{Incentives to New Dinar Loans}

38. New dinar loans would be incentivized by lower RRs, budget-based subsidy schemes that would induce banks to reach a certain level of non-euro assets (with this threshold excluding T-bills and NBS operations). This expansion toward dinar assets should, as far as possible, be self-funded (i.e., come from an expansion of dinar liabilities). Still, the case that it would be supported by an increase in euro liabilities should not be excluded. In this case, it would be crucial for banks to benefit from various alternatives to cover the asset-liability mismatch that would stem from a dinar asset expansion. This would require the provision of FX hedging instruments. Appendix I outlines in broad terms how this need for FX risk management instruments could be met.

\section{The CRISIS LIQUIDITY MANAGEMENT FRAMEWORK}

39. The Serbian banking system is largely immune to liquidity risks at the systemic level. The large liquidity buffers afforded by high RR rates in euro, and the large stock of shortterm liquidity draining operations carried out by the NBS would give it the capacity to release 
around EUR 400 million (via an emergency cut in RRs), and 150 billion dinar (by letting the repo portfolio come due) (Table 2). This capacity could be achieved without the need to resort to direct injections. In addition, the relatively embryonic nature of the money market makes the risk of systemic liquidity crisis stemming from an interbank contagion extremely unlikely.

\section{Table 2. Assets and Liabilities of the Serbian Banking System (Quasi-Cash Buffer Highlighted in Green)}

as of end-June 2009

Assets
Cash
Reserves at thecentral bank
required reserves
excess reserves
Other assets (include NBS repo)
Investments in Government Secunities
Investments in Other Fixed Income Secunities
Equity Investments in bank
Equity Irvestments in other non bank
Gross Loans
Interbank loans
Noninterbank loans
of which: inlocal currency
of whichindexed to foreigncurrency
of which: in foreign currency
of which: other indexed
Specific Provisions
Loans after Specific Provisions
Fixed assets
Total Assets

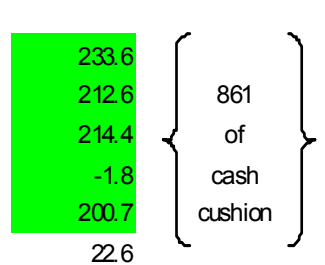

$\begin{array}{lr}\text { Liabilities } & \\ \text { Borrowing from NBS } & 1.9 \\ \text { Interbank Deposits } & 722 \\ \text { Non interbank Deposits } & 1028.5 \\ \quad \text { Of which: in foreign currency } & 706.6 \\ \text { Of which: in domestic currency } & 289.0 \\ \text { Of which: foreign currency index deposits } & 32 . \\ \quad \text { Of which: other indexed deposits } & 0.0 \\ \text { Loans } & 178.1 \\ \quad \text { Interbank } & 107.2 \\ \quad \text { of which: due to foreign banks } & 89.7 \\ \quad \text { Non Interbank } & 70.9 \\ \quad \text { of which: to parent banks } & n a \\ \text { Secunities issued: } & 0.3 \\ \text { of which: inforeign currency } & 0.0 \\ \text { Other liabilities and payables } & 145.4 \\ \text { Shareholders Equity } & \\ \text { Paid-in capital/common stock } & 336.4 \\ \text { Reserves } & 101.3 \\ \text { Retained eamings } & -4.4 \\ \text { Total Shareholder equity } & 433.2 \\ \text { Total Liabilities and Shareholders equity } & 1859.6\end{array}$

40. The liquidity crisis management framework has only recently come to the fore, and the current set-up was finalized partially under the pressure of circumstances and following the liquidity stress generated by the run of October 2008. The current last resort lending regulations were introduced in 2008, and additional regulations provide funding alternative for banks in case of liquidity stress, notably under the FSSP.

\section{A. Collateral Policy Issues}

\section{The last resort lending framework introduced in $\mathbf{2 0 0 8}$ has been assessed by $\mathbf{M C M}^{\mathbf{1 0}}$} as "generally in line with the internationally accepted goals of such facilities." It has increased the NBS operational flexibility by allowing it to accept a broader range of collateral, thus providing banks with greater access. Still, there are some recommendations to strengthen this framework, which are notably (a) making sure that the margining policy (haircuts) are in line with the risk profile of the underlying instrument; (b) adjusting the collateral list on an ongoing

\footnotetext{
${ }^{10}$ MCM TEC “crisis preparedness framework and capital account liberalization,” April 2009
} 
basis, taking into account the depth of the underlying market; and (c) increasing the legal and institutional options available to the NBS to collect claims (in case of transfer of receivables).

42. The financial crisis has shown central banks that cruise speed assumptions made on the credit quality and disposability of various collaterals can be severely crushed in a crisis. Several central banks still hold guarantees once deemed high quality, several months after intervening, essentially because the collateral that was taken at the time turned out not to have a market after the failure. This situation happened in a context where no provisions had been made for the disposal of legacy assets (be it in cruise time or in crisis time).

43. The collateral policy of the NBS should be defined in a more holistic fashion, rather than scattered in different regulations and directives. The methodology used for the calculation of haircuts should be described in a comprehensive fashion, together with the description of the different levels of eligibility attached to various instruments. Procedures for margin calls should also be established, should the market value of the collateral fluctuate significantly during the time span of the operation. The procedures used in case of asset disposal (see above), should also be documented.

\section{B. Public Sector Backing of Financial Stability-Related Operations}

44. Beyond the management of legacy assets, LOLR operations should generally be carried out under a clear and public commitment of the full backing of the central bank by the government. LOLR operations can be credible only if the general public trusts that the financial soundness of the central bank is not put at risk. The capital of the NBS may not suffice to absorb the losses on the collateral seized on the occasion of a large-scale bankruptcy. The government should either (i) provide an option to re-channel these assets towards an ad hoc structure, whose risk equity would be provided by the government; or (ii) establish institutionally that any realized or potential loss originating from a financial-stability motivated action should be offset by a budgetary transfer to the equity of the NBS (automatic recapitalization).

\section{DEVEloping The GoVernMent SECURIties MARKeT}

45. In May 2009, the MOF resumed the issuance of T-bills to finance the budget in the context of pressing budgetary needs. The volume of T-bills issued has increased steadily, as well as the average duration of T-bills stock, thanks to the introduction of 6-month and one-year bills in the summer of 2009 (Figure 9). A DMO is being set-up within the MOF. A workshop on public debt management, organized by the World Bank in the summer, has provided an interim assessment of the situation in terms of public debt issuance in Serbia, and to outline some medium-term development objectives for debt markets. The mandate of the DMO is currently being defined. Care should be taken that the mandate of the debt office is consistent with the need to provide effective coordination between monetary policy and fiscal policy as of need. 
Figure 7. Stock of T-bills per Maturity and Auction Key Features

(Bid to cover, allotted rate)
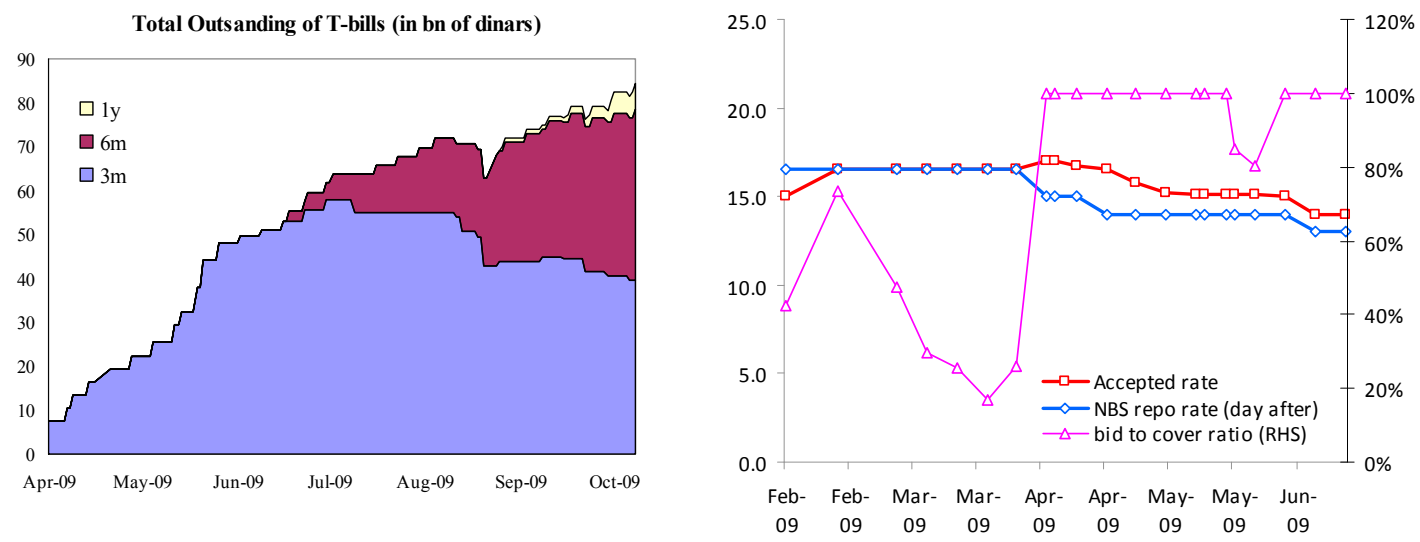

46. Current issuance arrangements have served the treasury well, and have helped to achieve relatively stable funding conditions. No auctions have failed since May 2009, and the auction modalities used, while not completely in line with international best practice, have allowed the requirements of investors to be met, essentially achieving yields higher than the NBS repo rate, while ensuring the funding needs of the treasury.

\section{Further improvements should be considered to promote the development of the} secondary market. First, the auction calendar should be streamlined. The re-opening of an already issued line (assimilation through the use of an identical international securities identification number (ISIN) code for re-issued securities) should be used by the treasury, as it would facilitate the creation of benchmark series, via regular issuance of securities at selected tenors to create high-liquidity issues. ${ }^{11}$ One weekly auction rather than three auctions would help to reduce the risk of "squeeze" and allow the current 15 percent allotment limit for successful bids to be lifted. A variable rate allotment process would also facilitate a more efficient pricediscovery process.

\section{The settlement dates should be harmonized so that all auctions are settled on the}

same day of the week. The use of a $\mathrm{T}+0$ settlement date for T-bills, while technically sound and in line with CPSS-IOSCO recommendations, ${ }^{12}$ should not be used as a default convention for all the auctions of the treasury. Cross-countries observation suggests that treasury issuance is generally carried out with a settlement lag, even when $\mathrm{T}+0$ is available, and actually used for some other operations (like buy-backs or cash management operations of the treasury). Having a longer settlement lag for auctions would create some scope for the development of the secondary market and the repo market, as treasurers could detach their bidding behavior from immediate

\footnotetext{
${ }^{11}$ Managers of the Central Security Registry and Depository mentioned that although this facility was technically available, the MOF never used it, and systematically created new securities (new ISIN codes) even in case of reopening of an existing line, thus preventing fungibility of the different issues.

${ }^{12}$ See the CPSS/IOSCO Report on "Recommendations for Securities Settlement Systems,” BIS, Basel 2001.
} 
liquidity management concerns (no need to "pre-fund" the auctions). One weekly single settlement date for treasury operations would allow treasurers to manage their liquidity gaps more actively, by selling T-bill holdings or using repos to bridge them.

\section{The establishment of a genuine debt strategy and the strengthening of the MOF} cash management are key prerequisites to further development of the T-bills market. Serbia's public debt is currently 93 percent foreign currency denominated. This legacy situation, inherited from the freezing of foreign currency deposits, has placed a lasting constraint on debt management. The foreign reserve position does not give sufficient leeway to swap some of this debt into dinar. For these reasons, the expansion of the dinar share of the public debt will have to be gradual. The cash management of the MOF will also need to be strengthened. The limited ability to forecast cash flows patterns accurately is currently the rationale for keeping a large portion of the T-bill issuance on short-term tenors. This concentration in short-term issues generates an important rollover risk that is a source of vulnerability for public finance, but also an obstacle to the development of a genuine yield-curve. Establishing better cash flow forecasts will allow lengthening the average duration of the domestic debt.

50. Better pricing information and primary dealership arrangements could be used for development of the secondary market. The DMO, the NBS, or a brokerage company could provide market participants with some pricing and dealing information via an Internet-based page that could be updated a couple of times per day with indicative and anonymous pricing information from large T-bill holders (for example, the price at which they would be willing to sell some of their holdings). The provision of brokerage services on over-the-counter markets would facilitate price discovery on the T-bill secondary market. Similarly, a Primary Dealership agreement, subject to maintaining minimum participation levels and market making responsibilities, could give auction participants some privileges (such as the right to purchase securities post-auction at the auction cut-off price, that is, the Non-Competitive Offers).

Although such a system is perhaps premature, the DMO should start studying such measures and consulting with market participants to assess which combination of incentives and obligations could be deemed acceptable and workable in the medium term. 


\section{Appendix Table I. Selected Country Experiences with Specific De-dollarization Measures}

\begin{tabular}{|c|c|c|c|c|}
\hline Countries & $\begin{array}{l}\text { Change in } \\
\text { Dollarization } \\
\text { During Period 1/ }\end{array}$ & Time Period & Measure & Description of the Measure \\
\hline \multirow[t]{4}{*}{ Angola } & $\ldots 2 /$ & 2001 & Encourage the use of domestic cash & $\begin{array}{l}\text { - Granting legal tender status to the local currency only } \\
\text { - Taxes and other payments in local currency } \\
\text { - Strengthening the quality of the payment system in local currency } \\
\text { - Improving the quality of the banknotes }\end{array}$ \\
\hline & & 2001 & Alternative financial instrument & $\begin{array}{l}\text { - Deeper money market } \\
\text { - Inflation indexed substitutes }\end{array}$ \\
\hline & & 2001 & Prudential regulation & $\begin{array}{l}\text { - Dollar indexed loans } \\
\text { - High FCD liquidity requirement ( } 50 \text { percent) }\end{array}$ \\
\hline & & & $\begin{array}{l}\text { Regulation discriminating against the use of } \\
\text { foreign currency }\end{array}$ & - Restrictions on dollar loans \\
\hline \multirow[t]{3}{*}{ Argentina } & & $2002-06$ & $\begin{array}{l}\text { Regulation discriminating against the use of } \\
\text { foreign currency }\end{array}$ & - Foreign currency loans only to exporters \\
\hline & -72 percent & $2001-02$ & Forced de-dollarization & $\begin{array}{l}\text { - Limit on cash withdrawals until } 2002 \text { for LCD and freeze until } 2003 \text { for FCD } \\
\text { (inflation indexed) }\end{array}$ \\
\hline & & $2001-02$ & Forced de-dollarization & $\begin{array}{l}\text { - Conversion of FCD and foreign-currency-denominated assets in peso at different } \\
\text { rate }(1.4 \mathrm{p} / \mathrm{US} \$ 1 \text { and } 1 \mathrm{p} / \mathrm{US} \$ 1)\end{array}$ \\
\hline \multirow[t]{2}{*}{ Armenia } & $\ldots 2 /$ & 2006 & Interest rate wedge & - Interest rate liberalization (increase in LCD interest rate) \\
\hline & & MEFP 2006 & Prudential regulation & - Limiting the operation of foreign exchange bureaus to retail operations \\
\hline \multirow[t]{3}{*}{ Bolivia } & $\ldots 2 /$ & 2006 & Taxation & $\begin{array}{l}\text { - Exemption of local currency deposits from the financial tax (made permanent for } \\
\text { FCD) }\end{array}$ \\
\hline & $\begin{array}{l}-6 \text { percent/ } \\
-20 \text { percent }\end{array}$ & Since 2003 & Public debt management & - Eliminating indexation of public debt to dollar \\
\hline & & & Prudential regulation & - Reserve requirement favorable to the use of local currency \\
\hline
\end{tabular}




\begin{tabular}{|c|c|c|c|c|}
\hline Countries & $\begin{array}{l}\text { Change in } \\
\text { Dollarization } \\
\text { During Period } 1 /\end{array}$ & Time Period & Measure & Description of the Measure \\
\hline & & & Alternative financial instrument & - Dollar indexed financial instrument as an alternative to FCD \\
\hline \multirow[t]{2}{*}{ Brazil } & & & Alternative financial instrument & - Inflation indexed securities \\
\hline & & & Public debt management & - External debt swapped for internal debt (domestic currency market development) \\
\hline \multirow[t]{2}{*}{ Chile } & -16 percent & 1989-97 & Alternative financial instrument & - Inflation indexed securities \\
\hline & +10 percent & 1984-86 & Public debt management & - Switch from dollar-denominated bonds to inflation-indexed debt \\
\hline Colombia & $\ldots 3 /$ & 1970s & Alternative financial instrument & - Interest rate indexed financial instrument \\
\hline \multirow[t]{2}{*}{ Costa Rica } & +6 percent & $2001-05$ & Prudential regulation & $\begin{array}{l}\text { - Equal RRs on deposits in colones and dollars } \\
\text { - Higher provisioning on dollar debt to non-exporters } \\
\text { - Additional liquidity requirement on foreign currency deposits }\end{array}$ \\
\hline & +6 percent & $2001-05$ & Alternative financial instrument & - Inflation-indexed debt \\
\hline Croatia & -14 percent & 1994-06 & Prudential regulation & $\begin{array}{l}\text { - Broadening the base for reserve requirement to prevent banks from borrowing } \\
\text { abroad via local nonbank intermediaries. } \\
\text { - Higher risk weights on unhedged foreign currency-denominated and indexed } \\
\text { loans } \\
\text { - New guidelines to banks on managing household and currency-induced credit } \\
\text { risk } \\
\text { - Broadening of the base of the FX liquidity requirement to cover instruments } \\
\text { indexed or denominated in foreign currency. }\end{array}$ \\
\hline Egypt & $\begin{array}{l}-29 \text { percent } \\
-34 \text { percent }\end{array}$ & $\begin{array}{l}1991-96 \\
1991-99\end{array}$ & Interest rate wedge & $\begin{array}{l}\text { - Financial sector liberalization } \\
\text { - Interest rate increase on local currency deposits }\end{array}$ \\
\hline Estonia & -17 percent & 1992-94 & Interest rate wedge & - Interest rate increase on local currency deposits \\
\hline Haiti & $\ldots 3 /$ & & $\begin{array}{l}\text { Discourage the use of foreign means of } \\
\text { payments }\end{array}$ & - RR in local currency for FCD to encourage banks to attract LCD \\
\hline Hungary & -16 percent & 1995-96 & Interest rate wedge & - Interest rate increase on local currency deposits \\
\hline
\end{tabular}




\begin{tabular}{|c|c|c|c|c|}
\hline Countries & $\begin{array}{l}\text { Change in } \\
\text { Dollarization } \\
\text { During Period } 1 /\end{array}$ & Time Period & Measure & Description of the Measure \\
\hline \multirow[t]{4}{*}{ Israel } & -29 percent & 1995-2002 & Public debt management & - Switch to domestic-currency-denominated bonds to finance budget deficits \\
\hline & & 1990-2002 & Prudential regulation & $\begin{array}{l}\text { - Strengthening supervision to ensure that banks maintain covered positions in } \\
\text { their foreign currency activities } \\
\text { - Different remuneration on RRs }\end{array}$ \\
\hline & & & Financial market development & - Development of hedging markets (derivatives) \\
\hline & & & $\begin{array}{l}\text { Discourage the use of foreign means of } \\
\text { payments }\end{array}$ & - Ban on foreign transfers of currency deposits between residents \\
\hline \multirow[t]{3}{*}{ Lao P.D.R. } & -57 percent & 1997-2004 & Interest rate wedge & - Monetary policy maintains high interest rates on local currency deposits \\
\hline & -18 percent & $1997-2000$ & Encourage the use of domestic cash & - Denomination of currency adapted to local business needs \\
\hline & & & $\begin{array}{l}\text { Administrative limitation on the use of foreign } \\
\text { means of payments }\end{array}$ & -Ban on the use of foreign currency in domestic transactions \\
\hline Lebanon & -4 percent & 1994-2006 & Prudential regulation & - Foreign currency lending limited to 60 percent of FCD \\
\hline Lithuania $^{4}$ & -30 percent & $1993-97$ & Interest rate wedge & $\begin{array}{l}\text { - Financial liberalization } \\
\text { - Interest rate increase on local currency deposits }\end{array}$ \\
\hline \multirow[t]{4}{*}{ Mexico } & -6 percent & 1995-2002 & Alternative financial instrument & - Inflation indexed securities \\
\hline & -6 percent & 1995-2002 & Prudential regulation & $\begin{array}{l}\text { - Ceiling on external financing } \\
\text { - Capital controls limiting access to FCD for firms }\end{array}$ \\
\hline & $\ldots 3 /$ & 1982 & Forced de-dollarization & - Conversion of dollar-denominated assets to Mexican pesos \\
\hline & & & Public debt management & $\begin{array}{l}\text { - Switch in debt management from dollar-denominated external debt to local } \\
\text { currency debt }\end{array}$ \\
\hline
\end{tabular}




\begin{tabular}{|c|c|c|c|c|}
\hline Countries & $\begin{array}{c}\text { Change in } \\
\text { Dollarization } \\
\text { During Period 1/ }\end{array}$ & Time Period & Measure & Description of the Measure \\
\hline \multirow[t]{3}{*}{ Nicaragua } & +8 percent & $1995-2000$ & Alternative financial instrument & - Dollar indexed financial instruments as an alternative to FCD \\
\hline & & & $\begin{array}{l}\text { Monetary regulation favoring domestic } \\
\text { currency }\end{array}$ & - Different remuneration on reserves requirements \\
\hline & & & Interest rate wedge & - A premium paid on dollar index deposit over dollar deposit \\
\hline \multirow[t]{4}{*}{ Pakistan } & -20 percent & 1998-2003 & Forced de-dollarization & - FCD freeze :redeemable in rupee immediately or for medium term bonds \\
\hline & -20 percent & $1998-2003$ & Taxation & - Elimination of tax exemption for new FCD \\
\hline & -20 percent & $1998-2003$ & Prudential regulation & - Disallowing the use of FCD as collateral \\
\hline & & & $\begin{array}{l}\text { Monetary regulation favoring the domestic } \\
\text { currency }\end{array}$ & - Special RR on FCD \\
\hline \multirow[t]{5}{*}{ Peru } & & 2007 & $\begin{array}{l}\text { Monetary regulation favoring the domestic } \\
\text { currency }\end{array}$ & $\begin{array}{l}\text { - Higher remuneration of LC RR } \\
\text { - Staff recommendation: higher premium on FCD insurance }\end{array}$ \\
\hline & & $1996-2007$ & $\begin{array}{l}\text { Monetary regulation favoring the domestic } \\
\text { currency }\end{array}$ & - Different RR (+34 percent for FCD) \\
\hline & -15 percent & $\begin{array}{l}2000-05 \\
\text { (since then } \\
\text { further } \\
\text { decline }\end{array}$ & $\begin{array}{l}\text { Administrative limitation on the use of foreign } \\
\text { currency }\end{array}$ & - Requirement to list prices in domestic currency \\
\hline & -12 percent & 1988-89 & Taxation & - 2 percent tax on check payment in foreign currency \\
\hline & -20 percent $2 /$ & $1985-1987$ & Forced de-dollarization & $\begin{array}{l}\text { - Conversion of dollar-denominated assets in Peruvian pesos. (FCDs reintroduced } \\
\text { two years later) }\end{array}$ \\
\hline
\end{tabular}




\begin{tabular}{|c|c|c|c|c|}
\hline Countries & $\begin{array}{l}\text { Change in } \\
\text { Dollarization } \\
\text { During Period 1/ }\end{array}$ & Time Period & Measure & Description of the Measure \\
\hline & & & Prudential regulation & $\begin{array}{l}\text { - Foreign currency lending to unhedged borrower limited } \\
\text { - Mandatory evaluation of currency risk for credits in foreign currency }\end{array}$ \\
\hline & & & Public debt management & - Issue of local currency-denominated government and central bank securities \\
\hline & & & Financial market development & $\begin{array}{l}\text { - Development of hedging facilities } \\
\text { - Development of domestic currency market }\end{array}$ \\
\hline Poland & -47 percent & 1989-93 & Interest rate wedge & $\begin{array}{l}\text { - Financial sector liberalization } \\
\text { - Increase in local currency interest rates }\end{array}$ \\
\hline Turkey & -16 percent & 1995-96 & Interest rate wedge & - Hikes in central bank interest rate \\
\hline \multirow[t]{2}{*}{ Uruguay } & $\ldots 3 /$ & $2001-$ & Alternative financial instrument & - Introduction of a inflation indexed unit of account for debt/financial assets \\
\hline & & & Prudential regulation & $\begin{array}{l}\text { - Higher liquidity requirement for dollar operations } \\
\text { - Higher capital requirement for dollar loans to the nontradable sector } \\
\text { - Higher premium on FCD insurance }\end{array}$ \\
\hline Vietnam & -15 percent & & Prudential regulation & - Foreign currency loans restricted to certain borrowers \\
\hline
\end{tabular}

Note: Successful de-dollarizations in noncrisis cases are bold.

1/ Calculations based on data in the Levy-Yeyati database. It includes 107 countries between 1970 and 2004, and the average FCD for the sample is 30 percent. 2/ Recently started de-dollarization.

$3 /$ No significant change in dollarization.

4/ Lithuania pegged its currency to the euro in the context of a currency board while most FCDs were denominated in dollars. The subsequent trend appreciation of the euro vis-à-vis the dollar probably entrenched appreciation expectations. 


\section{Appendix I. A Strategy for the Dinarization of FX Loans ${ }^{13}$}

\section{The credit conversions from FX to dinars are a forceful, but also the most} problematic, dinarizing measure. Forceful because they focus on the existing credit stock and change the banks' balance sheets immediately. Problematic because they are likely to be opposed by both banks and households, and may require a legal enforcement.

52. In summary, the best strategy would seem to consist of (a) focusing on a well-defined and small market segment (such as consumer credits); (b) providing incentives combined with moral suasion for banks to become active in such conversions; (c) encouraging banks to restructure converted credits to suit borrowers needs; and (d) taking part of the resulting FX risk off the banks' balance sheet (and perhaps distributing further). If successful, the scheme could be broadened to other segments and/or the involvement of other banks could be enforced. It might also be opportune to think of the conversions only after there is a progress in dinarization of newly granted credits.

53. In principle, the conversions would imply that an FX borrower takes an additional dinar credit that is used to repay the outstanding present value of its current FX credit. Technically, it may take many forms; for example, the combination of forwards, swaps, and options. The fact that most of FX credits are in fact dinar credits with an indexation clause could make conversions easier. A market-friendly measure could involve splitting the credit contract into two: a pure dinar credit and a stream of FX forward contracts (guaranteeing the FX equivalent for both the bank and the borrower). Then, the FX forwards could be sold to a final holder of the FX risk (whoever that is going to be, such as the NBS or an international institution).

54. All other things being equal, conversions would be opposed by both borrowers and the banks because of the following:

- $\quad$ Borrowers would not like it, because dinar interest rates and therefore actual monthly interest payments are higher than on their $\mathrm{FX}$ equivalents.

- Banks would oppose it, because it would create an open FX position on their balance sheet.

This resistance would need to be overcome, either by enforcement or by inducement schemes.

\section{Enforcement schemes}

55. In the extreme, the credits could be converted by a law. For instance, a law could declare the FX indexation clauses on dinar credit contracts as void. This is a measure of last resort, although not unheard of in modern history. For instance, the United States has done it

\footnotetext{
${ }^{13}$ Prepared by David Vavra, MCM consultant.
} 
twice in the last century (gold indexation clauses to contracts were cancelled). Most recently, similar measures were discussed in the context of solving the Latvian crisis.

56. There are various kinds of soft "enforcement" schemes through moral suasion of the banks. For instance, participating banks could be granted access to some NBS facilities a la the Vienna accords. Alternatively, the NBS could introduce a "dinarization index" as a simple composite measure of an individual banks' balance sheet dinarization and tie certain benefits to improvements in such an index.

\section{Inducement schemes}

57. All inducement schemes would have to address the interest burden of borrowers and the FX risk fears of banks.

\section{Borrowers}

58. To address the concerns of borrowers, the conversion would have to guarantee that the new dinar credit has the same (or lower) nominal interest payments as the original FX credit. This assertion is based on the assumption that borrowers (and creditors alike) look mostly at the absolute size of the payment every period and not the interest rate as such.

\section{Assuming higher dinar than FX nominal interest rates, lower dinar interest}

payments could be achieved by restructuring the converted credit, such as by extending the tenors and providing grace periods by commercial banks. To encourage this, the NBS would have to guarantee the banks that such restructuring would not harm their prudential standards or mandatory capital requirements. This should be doable - a similar guarantee is provided by the Vienna accords and some banks have already used it in converting FX to dinar credits (e.g., the EFG). One could also think of public subsidies to dinar interest rate payments (e.g., to certain types of borrowers or credits). For instance, the NBS (or budget) could choose to subsidize dinar interest rates under certain conditions; for example, for banks that achieve certain "targets" in terms of dinarization of their balance sheets (see earlier).

60. Such subsidies are, of course, problematic. They may introduce harmful distortions that might be difficult to remove later on. It is also a drain on the already strained fiscal budget.

61. However, if at all, the economic downturn is the best period for introducing interest subsidies. Additionally, if the NBS pays the bill, the fiscal budget will not be affected —at least according to European Union (EU) rules. 


\section{Banks}

62. The banks would have to find a way of disposing of the FX exposure created by the conversion. Over time, this can be done by finding more dinars on the liabilities side. In this vein, the conversions would also help promote dinarization of the deposits. However, much of the FX risk would have to be dealt with immediately.

63. There will be no market (i.e., no market-maker, no price) for such FX risks, for several reasons: (a) there are not enough long-term dinar instruments to price long-term dinar credits; (b) the instruments to hedge an FX exposure on various kinds of mortgages (and other long-term credits) are fairly complex; and (c) such markets do not exist even for more developed and externally convertible emerging currencies (such as CZK or PLN).

64. A public institution would have to step in to absorb (at least a part of) the FX risk and to play the market maker by setting the price for this risk.

65. The NBS would be a natural candidate for absorbing the risk, for several reasons: (a) it has the monitoring authority of the banks; (b) it has a strong bargaining position with banks over the price of the FX risk; (c) if public subsidy is involved in pricing of the risk, it must be a domestic authority; and (d) it is hard to imagine that any foreign institution would enter into a direct transaction of this sort with a local commercial bank without central bank involvement.

66. However, the NBS need not be the final holder of the risk. Perhaps the NBS could merely distribute the risk to final counterparties, such as an international institution (e.g., the European Central Bank (ECB) or other donor banks) or a regional fund set up from public money for that purpose.

67. Passing the risk further on (for example, by establishing swap lines) could reduce the pressure on the NBS reserves. The risk taken by the NBS should be in a reasonable proportion to the size of the FX reserves, otherwise the scheme would not be credible. The ECB would be an ideal counterparty in this case, because it is the LOLR in EUR, and Serbia will have to enter the EMU at one point in future (assuming EU membership), providing a terminal (although unknown) point for the maturity of such swap lines. However, similar arrangements with other institutions would also be possible.

68. In the absence of the market, the price of the FX risk would become a matter of agreement between a commercial bank and the NBS. The price can be based on a rolling variable rate or a fixed rate over the entire period of the risk. A fixed rate would be ideal, but it would have to be based on a view of economic fundamentals over an extended period of time, and the banks may not share the same view as the NBS. The variable rate is less preferable, because it provides only a limited risk coverage, but could be determined more easily based on existing benchmark rates; for example, 12M T-bill rates (or longer if available and sufficiently liquid). It would then be rolled over until the maturity of the risk. In any case, part of the FX risk should be left with the commercial banks. Commercial banks should now be better aware of the 
risks from unhedged exposures of their clients, and hence should be willing to share part of the risk. At the same time, that the price the NBS would pay for the risk should leave sufficient incentive for the banks to hedge themselves by finding dinar deposits over time. Passing the risk further to an international organization or fund would be highly desirable to increase the scope of the conversions and reduce the pressures on NBS currency reserves. Assuming the ECB will not volunteer to become a garbage bin for such risks, establishing a dedicated regional or international fund for that purpose could be a viable option.

\section{Acting as a market maker, a dedicated fund would price the FX risk by providing} forwards and swaps to the regional central banks involved in credit conversions. With large international institutions as investors, the fund would enjoy a premium credit rating. By dealing only with national central banks, it would face little counterparty risk. Such a fund would also be better positioned as a market maker than the central bank. For instance, the TCX (Currency Exchange Fund, http://www.tcxfund.com/, based in Amsterdam) is an example of a fund operating along similar lines in the developing world, albeit on a smaller scale than needed here. 
Appendix II. Using T-bills Issuance as a Monetary Management Instrument

Figure 8. Channeling of Flows between the NBS, the Treasury and Commercial Banks

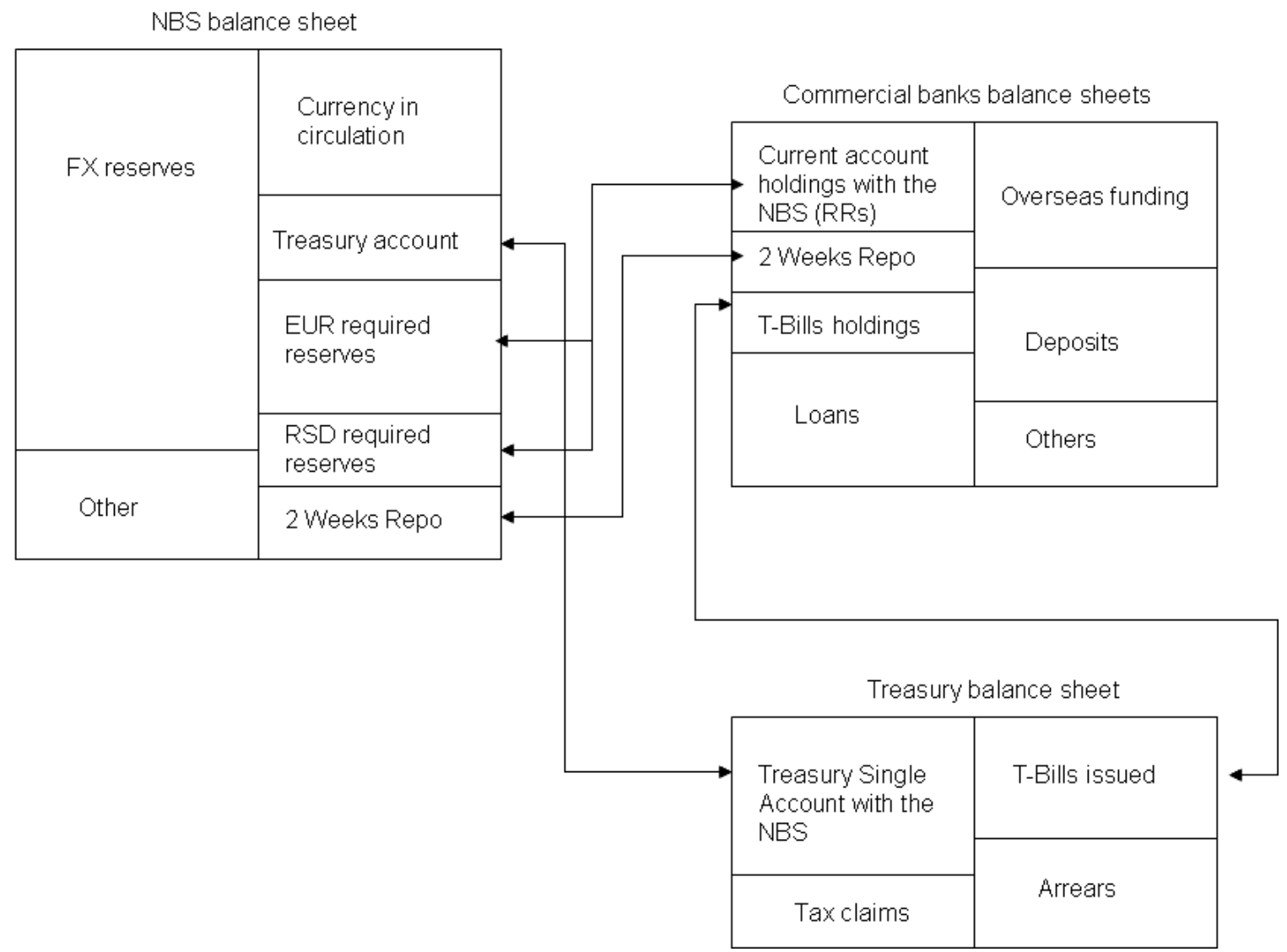

70. Using T-bills as a monetary management instrument, while requiring the design of an efficient coordination framework, would have many immediate merits. The first would be to give greater operational flexibility to the NBS to scale down its repo book as necessary, and to distinguish structural liquidity draining operations (and their cost) from the signaling of monetary policy, that is, given through its key rate (the two-week repo). The second would be to help the treasury/DMO to achieve a more stable pattern of security issuance throughout the business cycle (i.e., not having to scale down issuance too markedly when the fiscal situation improves). Larger issuance would also support the development of the secondary market and the repo market (see below), facilitate the emergence of benchmark security, and also increase banks holdings of first quality dinar-denominated collateral (see section III). 
71. The flow chart on the previous page outlines the existing channeling of flows between the NBS, the treasury, and commercial banks. The treasury operations have, in principle, no liquidity impact, unless they affect the structural balances held by the treasury with the NBS. The proceeds of T-bills issuance are used for budget execution and come back instantaneously (or with a short leg) to the banking system. In this environment, the repo rate (operated as a standing facility), creates a de facto floor to the T-bill interest rate because of the unlimited access of banks. Unless banks anticipate a cut in the repo rate, they will limit their bidding to a rate at least equivalent to the repo rate.

Figure 9. Channeling Liquidity in System Where T-bill Issuance Would be Used to Drain Structural Liquidity

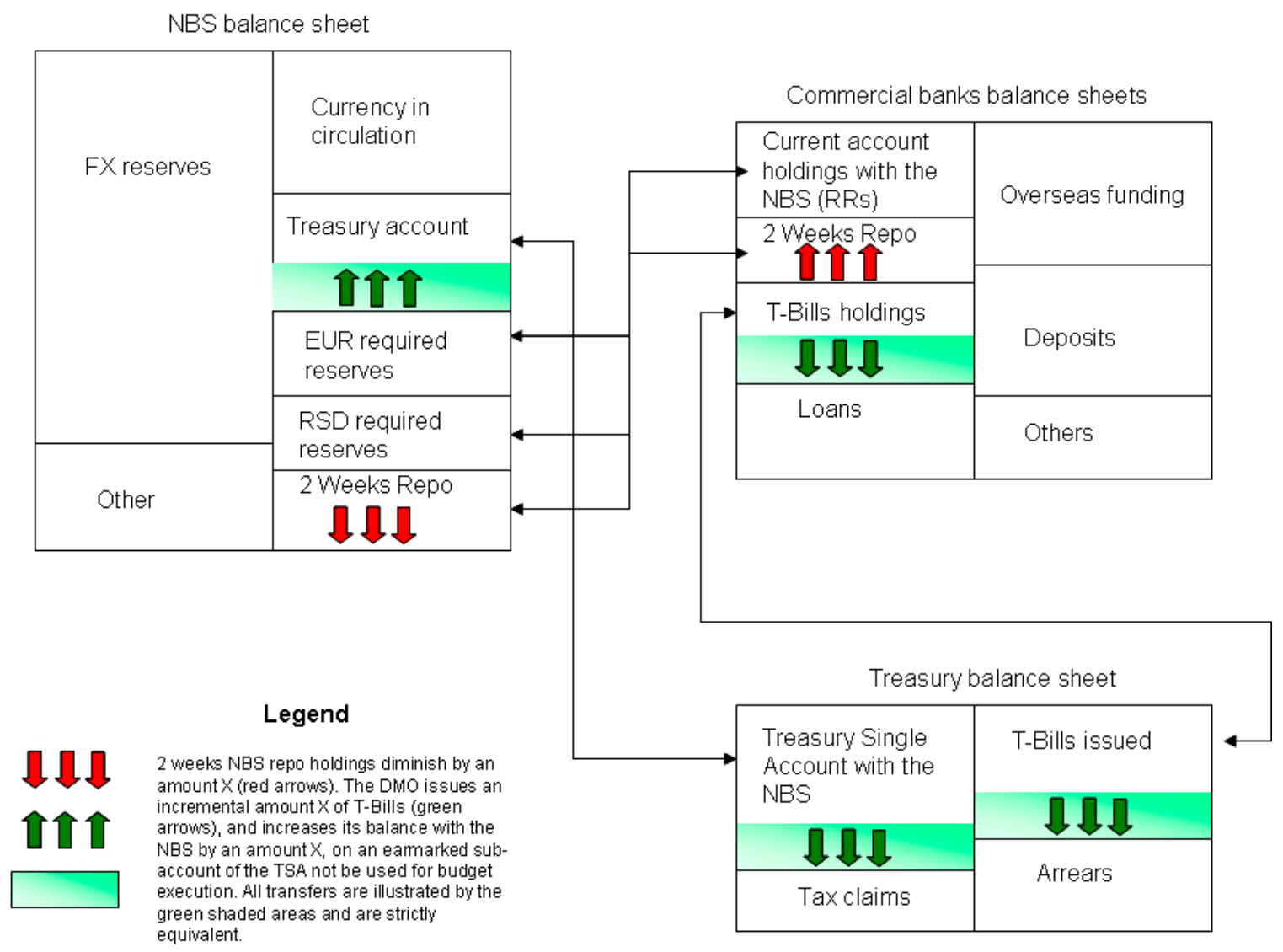

72. The graph above outlines how liquidity would be channeled in a system where Tbills would be used to drain structural liquidity in the system. First, some liquidity would be released from the NBS repo by a rationing of bids to the repo. This liquidity would be absorbed by an incremental issuance of T-bills whose proceeds would be deposited in an escrow account with the NBS. The blockage of this amount for a duration corresponding to the life-to-maturity of the underlying T-bills would provide the necessary liquidity draining that was provided for by repo operations. 
73. Still, the length and magnitude of the sterilization would not be bound by the past amount of T-bills issued for "monetary reasons." Releasing liquidity could be done easily, either by letting the treasury dispose of some of the amount standing on the escrow account (in the context of budget execution), or by allowing the treasury to channel some of these balances towards an account with a commercial bank, or towards a parastatal entity having an account with a commercial bank. The steering of the overall balance on these "escrow accounts" by the NBS could help to handle some unforeseen autonomous developments that would contract the overall systemic liquidity beyond the level of required reserves.

\section{Institutional and Operational Aspects: Coordination Debt Management Office/NBS}

74. Using T-bills issuance for liquidity draining will require a high level of coordination between the newly established DMO and the NBS. This coordination does not mean that the NBS will meddle into pure debt management considerations. The DMO will offer its service to the NBS, and the NBS will benefit from the DMO infrastructure to pursue its liquidity draining objectives, without infringement to the DMO mandate of minimizing the cost of the public debt.

75. To achieve this adequate level of coordination, the DMO and the NBS will have to set out a working agreement (a Memorandum of Understanding could be an adequate format) that will outline the following:

- The modalities to be used to define the target amount for the "escrow account" (horizon, frequency of the potential re-sets).

- The modalities under which some liquidity will be released, if need be, from the "escrow account," be it at the request of the NBS or at the request of the DMO (to deal with unexpected changes in the structural liquidity situation that the NBS could not handle with its traditional instruments).

- The modalities under which the NBS and the DMO will exchange information on liquidity management and meet to define DMO participation to the liquidity draining operations.

76. Other routine technical aspects related to $\mathbf{T}$-bill issuance will be left at the entire discretion of the DMO, in particular, if they simply relate to the "traditional" mandate of the DMO. This coordination principle will need to be provided for in the mandate of the DMO, so that technical divergence of views does not put at risk the whole framework of the DMO/NBS collaboration. The NBS will have to ascertain that its liquidity forecast is accurate enough to make sure that the DMO undertakes only operations corresponding to the structural part of the liquidity surplus, and use its own instruments to handle the most volatile component of excess liquidity. 


\section{Box 3. T-bills for Monetary Management, Advantages and Key Challenges}

Using larger T-bills issuance to gradually phase out the huge outstanding amount of NBS repo operations (and replacing repos with an "earmarked sterilization account of the treasury" on the liability side of the NBS balance sheet) would have several merits.

First, it would pave the way to a larger T-bill market, allow banks to replace repo operations with a more versatile investment vehicle (allowing sales, interbank repo operations) and provide additional amounts of first quality collateral to support capital market developments.

Second, the market-driven price determination of T-bills auctions (by opposition to NBS repo operations conducted as a de facto standing facility) would also help in creating disincentives to "hot money flows." Larger flows towards Serbia's T-bill market would push interest rates downwards, thus reducing incentives along the way, while the NBS could keep on using its key rates to convey its monetary stance (this would de facto allow the NBS to run structural liquidity draining efficiently without prejudice to the signaling role of its repo rate). Replacing the stock of repo with T-bills should in principle have no impact on T-bills yield curve as the liquidity needed to absorb this supplemental issuance would be released by a gradual reduction in the repo outstanding.

This approach, despite its many merits, also has several caveats when CB/MOF relationships happen to be difficult. Macedonia's experience, after a relatively quiet start in 2005 , got off tracks rapidly, partly owing to an unplanned surge in sterilization needs, but also to a non-collaborative stance of the treasury/MOF. This failure was due, inter alia, to:

1. The decision to split the curve between the CB and the treasury. This led to a spike on the segment of the curve where the bank had to concentrate the issuance for monetary purposes, that is, the three-month segment). 2. Some issues related to the way auctions were conducted. Larger banks were rigging T-bill auctions, (although it should be a problem for CBBs too), and this gave rise to constant criticism by the Treasury of the NBMK's handling of the auctions.

3. Conflicts of objectives between the DMO and the CB. The DMO has a narrow mandate (debt cost optimization), while the central bank has a more general mandate of systemic liquidity management and domestic market development (although the former should be shared by the DMO).

Balancing the potential costs and benefits seems an important prerequisite. Domestic market development motives should be understood and shared with market participants, otherwise the potential confusion created between monetary and budget policy objectives as well as responsibility/accountability issues between the central bank and the MOF may not be worth the effort. Conflicting incentives were key to Macedonia's failure: the DMO in Macedonia had a clear mandate to minimize budget costs and they were against having to issue longer maturities (hence more expensive). Although the MOF had very little funding needs at the time the Minister of Finance resented the central bank issuing T-bills "in his name" and charging higher interest, even though the central bank paid the interest on the T-bills (monetary policy costs were not transferred to the treasury, and consequently not an issue). The Minister believed interest rates should be much lower and no point in sterilizing. In the end the central bank started issuing its own bills again - for a while the MOF tried to compete by getting some buyers to accept lower interest rates on its auctions (in tiny quantities or at different maturities) — but in the end Macedonia started to run a deficit and MOF interest rates jumped up again. The bottom line of Macedonia's experience is that petty rivalries between the MOF and the central bank (such as personal issues or resentment over pay) or a more fundamental divergence of views on monetary policy implementation, can represent a significant obstacle to close coordination. 


\footnotetext{
The Macedonia experience (and others) highlights a set of lessons on the conditions necessary to make such approach a success. Using treasury security issuance for monetary management purposes can be effective only:

1. When MOF/CBs go completely hand in hand (or when the treasury is completely dominated by the central bank, e.g., Trinidad, India, or Korea).

2. When there is extremely limited CB meddling in DMO matters, coupled with a favorable fiscal situation, that is, structural primary surplus achieving a "de facto" large drain on the liquidity (e.g., in Brazil, where the DMO is only committed to a given amount on its account with the CB).

3. When all the issuance is actually based on monetary motives, obviating any risk of a DMO/CB turf fight (e.g., countries like Uganda where T-bills are used only to offset the liquidity impact of aid flows, and where the treasury would have no point in issuing because nearly 100 percent of funding is concessional).

4. If DMOs are not established on the basis of too narrow mandates and too independently from the MOF and the CB. DMOs overlooking the specific externalities of public sector debt issuance, and the need to coordinate with monetary authorities, can have a counter-productive impact (especially when the stakes in terms of debt service optimization are dwarfed by systemic liquidity management issues).
} 